\title{
Assessment of the Suitability of Aromatic and High-Bitter Hop Varieties (Humulus lupulus L.) for Beer Production in the Conditions of the Małopolska Vistula Gorge Region
}

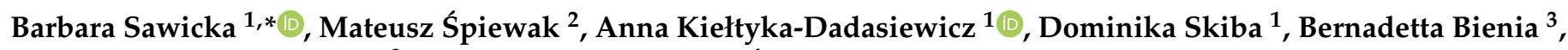 \\ Barbara Krochmal-Marczak ${ }^{3}$ and Piotr Pszczółkowski ${ }^{4}$
}

1 Department of Plant Production Technology and Commodity Science, University of Life Sciences in Lublin, Akademicka 15 str., 20-950 Lublin, Poland; anna.kieltyka-dadasiewicz@up.lublin.pl (A.K.-D.); dominika.skiba@up.lublin.pl (D.S.)

2 The Chmiel-Tech Company, Szczekarków 16, 24-313 Wilków, Poland; mateuszpiotrspiewak@o2.pl

3 Department of Plant Production and Food Safety, Carpathian State University in Krosno, Dmochowskiego 12 str., 38-400 Krosno, Poland; bernadetta.bienia@kpu.krosno.pl (B.B.); barbara.marczak@kpu.krosno.pl (B.K.-M.)

4 Experimental Station for Cultivar Assessment of Central Crop Research Centre, Uhnin, 21-211 Dębowa Kłoda, Poland; p.pszczolkowski.inspektor@coboru.gov.pl

* Correspondence: barbara.sawicka@up.lublin.pl; Tel.: +48-81-445-6787

Citation: Sawicka, B.; Spiewak, M.; Kiełtyka-Dadasiewicz, A.; Skiba, D.; Bienia, B.; Krochmal-Marczak, B.; Pszczółkowski, P. Assessment of the Suitability of Aromatic and High-Bitter Hop Varieties (Humulus lupulus L.) for Beer Production in the Conditions of the Małopolska Vistula Gorge Region. Fermentation 2021, 7, 104. https://doi.org/10.3390/ fermentation7030104

Academic Editor: Bin Tian

Received: 1 June 2021

Accepted: 22 June 2021

Published: 30 June 2021

Publisher's Note: MDPI stays neutral with regard to jurisdictional claims in published maps and institutional affiliations.

Copyright: (c) 2021 by the authors. Licensee MDPI, Basel, Switzerland. This article is an open access article distributed under the terms and conditions of the Creative Commons Attribution (CC BY) license (https:// creativecommons.org/licenses/by/ $4.0 /)$.

\begin{abstract}
The aim of the study was to assess the yield of cones and the quality of six hop varieties ("Iunga", “Lubelski", "Sybilla”, “Magnum", “Lomik”, “Marynka”) in terms of their suitability for beer production, under the conditions of the Małopolska Vistula Gorge Region $\left(21^{\circ} 53^{\prime} \mathrm{E} ; 51^{\circ} 16^{\prime} \mathrm{N}\right)$ (2015-2017). The scope of the research included the determination of the yield of cones and their physicochemical properties, as well as determination of the contents of hop resins and essential oils. In bitter varieties, the ratio of alpha-acids to beta-acids was stable, while, in aromatic varieties, it was variable. In the essential oils of the studied hop varieties, compounds with myrcene and $\alpha$-humulene were identified and dominated the profiles. "Iunga", "Sybilla", "Lubelski", and "Lomik" were rich in monoterpene hydrocarbons, mainly myrcene, while there was a bit more $\alpha$-humulene in the "Marynka" variety. "Magnum" was characterized by an even distribution of monoterpenes and sesquiterpenes. The "Magnum variety turned out the most useful for the brewing industry in this region. The Małopolska Vistula Gorge Region is a region where hops not only achieve a high yield of cones, but also good-quality. The bitterness and aroma content of the hops in this region is high.
\end{abstract}

Keywords: hop; essential oils; $\alpha$-acid; physicochemical properties; varieties

\section{Introduction}

Hops (Humulus lupulus L.), from the Cannabaceae family, is a perennial, wind-pollinated, dioecious plant. This plant species grows spontaneously in nature in temperate climate zones, between latitudes of $35^{\circ} \mathrm{N}$ and $55^{\circ} \mathrm{N}[1,2]$. A fully developed plant has several main roots (8-10). Plants of this species are characterized by a strongly developed above-ground part and a strong root system. The root of $H$. lupulus has shortened, perennial stems that grow 12-15 cm deep into the soil. In spring, shoots grow out of the stump and run on guides. In the aboveground part, there are vegetative organs of which the main function is the production of organic components in the photosynthesis process, and generative organs of which the function is the sexual reproduction of plants. Female and male flowers appear on separate plants. Common hops are a dioecious species. Male and female plants are morphologically identical and are best distinguished in the flowering phase. Male flowers are 5-6 $\mathrm{mm}$ in diameter and are arranged in paniculate, highly branched inflorescences. They have a five-fold perianth and five stamens. Female flowers have a strongly reduced perianth and their pistils are very extensive. The posts are devoid of necks, and the two 
thread-like birthmarks are located directly on the single-chamber ovary. At the base of each flower, there is an inflorescence leaf. The female flowers are gathered in inflorescences composed of 20-60 flowers, placed in pairs on a short cushion. Unfertilized female inflorescence are commonly called cones (strobiles). These hop cones consist of a central axis (spindle), bracts, and bracteoles, where glandular trichomes form lupulin glands, which are the most important source of secondary metabolites (resins, essential oils, and tannins) for beer production [2]. There is a single ground cover leaf above each pair of flowers. During the flowering phase, both the foliage and the cover leaves are heavily reduced and invisible. After pollination, the stigmas of the pistils dry up quickly, and then the leaf and cover leaves begin to grow, the seed deposit also lengthens, and the hop inflorescences transform into inflorescences called cones. The fruit is a single-seed peanut. Cones only form on female hop plants. They develop regardless of whether the flowers have been fertilized and produced seeds. Seedless cones are a better raw material for the brewing industry because they are characterized by a more compact habit, have adherent leaves, and a higher content of secondary metabolites. For this reason, only female hops are grown on production plantations. These plants are propagated vegetatively. A characteristic feature of hops is the presence of external lupulin glands, in which the secondary metabolites specific to this species, i.e., hop resins and oils, are collected. Lupulin glands are found on the lower surface of hop leaves, but are most numerous in the cones. On the leaves of cones, in the part adjacent to the sediment, their accumulation is so large that they form a yellow, slightly sticky powder called lupulin. The amount of lupulin and its composition depend on the variety of hops, the growing area, and the meteorological conditions during the growing season $[1,3,4]$. The main ingredients that give the characteristic flavor of beer are alpha acids, which come together with humulones and beta acids to form soft resins. There are also hard resins in the hop cones, which do not have greater, significant value, and tannins, which clarify beer, increase foam durability, and the aromatic hop oils affect beer aroma [5-8]. Hops are mainly used in the brewing, cosmetic, and pharmaceutical industries $[1,7,8]$.

Hops are industrial, special plants, grown for cones, which are the second most common brewing raw material after barley. Apart from numerous functional properties (medicinal, cosmetic, brewing, and others), the economic conditions of the world market determine, in particular, the cultivation of this species. The world hops cultivation area is about 99,577 ha, which corresponds to $8000-10,000$ tons of alpha acids [9]. The production of alpha acid regularly exceeds 5000 tons. The demand for alpha acids is estimated at around 8000 tons; assuming that an average of $4.1 \mathrm{~g}$ per hectoliter of beer is needed. The hop content of beer varies depending on the type of beer (especially in terms of a bitter taste) and the type of hops used. As a result of technological progress and the increasingly clear preference for less-bitter beer by consumers, the hops area decreases year by year [9].

A characteristic feature of the cultivation of this species in many countries is its concentration in specific regions. An example is the concentrated cultivation of hops in Bavaria (Germany) or in the US river valleys [10-14].

In 2019, Poland was fourth in Europe and sixth in the world in terms of hops cultivation area. In terms of hop production, Poland ranks third in Europe and fifth in the world [9]. Although world beer production is growing, the demand for alpha acids is only increasing slightly. As supply currently exceeds demand, average contractual and free market prices for hops are relatively low. Both aromatic and high-bitter hops varieties are used for cultivation [1,3-5].

Recently, a global trend to decrease the production of hops has been observed, which results from the implementation of modern brewing technologies, which means that less hops are needed for production. Breweries increasingly use processed products in the form of granules and hop extracts; thus, the use of pressed hop cones is decreasing. In years of good harvest, dishonest companies processing hop cones buy the surplus of raw material at very low prices, store it, and then sell it in the years of crop failure $[3,4,15]$. 
Hops are mainly used for the production of beer; therefore, the production of hops mainly meets the requirements of the brewing industry. This branch of industry uses about $95 \%$ of all raw hops in Poland $[1,3,14,15]$. The growing worldwide popularity of artisanal beer from microbreweries has, in recent years, favored the cultivation of local hop varieties, thus exceeding typical cultivation boundaries and going beyond recognized hop varieties $[1,3]$.

An important activity influencing the selection of varieties for hop production by producers is consultation with the processing plant with which they intend to cooperate. In such a plant, the needs of the market (brewing, pharmaceutical, or cosmetic sectors) are precisely known and production is adapted to the customer's needs. Other factors influencing the choice of a cultivar are topography, climatic conditions, and meteorological conditions $[3,4,16]$.

In general, currently, more than 200 different varieties of hops are grown worldwide. Traditionally, only plants from the taxonomic variety Humulus lupulus var. lupulus are used. Original varieties were prepared by selecting the fastest growing and most resistant plants with a good yield of cones from natural wild populations. Later, due to higher demands for qualitative properties, gene sources from other continents were also used. Hop varieties are classified into three categories on the basis of their use in brewing beer: aromatic, hot, and dual-use. Furthermore, hop varieties are classified on the basis of the content of hot acids (aromatic, hot, and high-content varieties) [1,2,6]. For the brewing industry, which is the main recipient of hops, the most important component of cones are alpha-acids. These are what give beer its specific bitterness and flavor. A high alpha acid content is, therefore, a prime consideration to take into account in the breeding of new hop varieties, especially bitter hops. The first varieties of this type, such as the English "Northern Brewer" or the American "Cluster", reached concentrations of alpha acids in the range of 5.5-10\%. In newer varieties, such as "Hercules" or "Rubin", the content of this ingredient reached $12-17 \%$ and $9-12 \%$, respectively [1]. In the cones of the American variety "Summit", or "Pick", the alpha acid content was as high as 17-19\% [14]. Due to economic reasons, the content of alpha acids being increased is also an important feature for aromatic varieties, although for this type, the most important factor is a noble hop aroma. Modern aromatic hop varieties contain $5-8 \%$ alpha acids, almost twice as much as old varieties, e.g., "Żatecki" (2.5-4\%). An important element of progress in hop breeding is establishing a benchmark against which to measure yield fluctuations or alpha acid concentrations. In Poland, in the case of aromatic varieties, the role of the standard was best fulfilled by the variety "Lubelski", which was tested in comparative experiments. For bitter varieties, the "Marynka" variety was adopted due to such a pattern $[4,6,7,15]$. Hence, the aim of this research was to evaluate the aromatic and high-bite varieties of hops in terms of their usefulness in specific, local soil and climatic conditions of the Małopolski Poland Vistula Gorge. Thanks to this, it will be possible to assess the impact of soil and weather conditions occurring throughout the growing season on the content of alpha acids and essential oils in the hops of aromatic and highly bitter varieties, popular in the Polish and European hop markets. The results of this research will help, in the future, to develop a forecasting model for weather attributes to predict alpha-acid content, one month before hop cones are harvested.

An alternative research hypothesis assumes that the selection of the right varieties for the production of hop cones will allow for the proper selection of raw materials for beer production and the obtaining of a product with an optimal content of alpha acids and essential oils, in the specific soil and climatic conditions of the Małopolski Poland Vistula Gorge, in comparison to the null hypothesis that hop varieties do not exert any influence on the quality of hops raw materials in this region.

\section{Material and Methods}

The studies were designed as strict field experiments with the randomized block method, in 3 replications. They were carried out in four towns: Zastów (A), Szkuciska (B), 
Brzozowa (C) and Majdany (D), on semi-subsistence farms in the region of the Małopolska Gorge of the Vistula. Six varieties of hops were tested. The location of the plantations is shown in Table 1 and Figures 1-4.

Table 1. Location and size of the studied hop plantations.

\begin{tabular}{ccccc}
\hline No & Location & Geographic Location & Hops Growing Area [ha] & $\begin{array}{c}\text { The Share of Hops in } \\
\text { the Sown Structure [\%] }\end{array}$ \\
\hline 1 & Zastów (A) & $51^{\circ} 16^{\prime} \mathrm{N} ; 21^{\circ} 52^{\prime} \mathrm{E}$ & 2.0 & 23.5 \\
\hline 2 & Szkuciska (B) & $51^{\circ} 14^{\prime} \mathrm{N} ; 21^{\circ} 49^{\prime} \mathrm{E}$ & 2.0 & 11.8 \\
\hline 3 & Brzozowa (C) & $51^{\circ} 14^{\prime} \mathrm{N} ; 21^{\circ} 50 \mathrm{E}$ & 2.5 & 17.7 \\
\hline 4 & Majdany (D) & $51^{\circ} 13^{\prime} \mathrm{N} ; 21^{\circ} 49^{\prime} \mathrm{E}$ & 2.0 & 20.2 \\
\hline
\end{tabular}

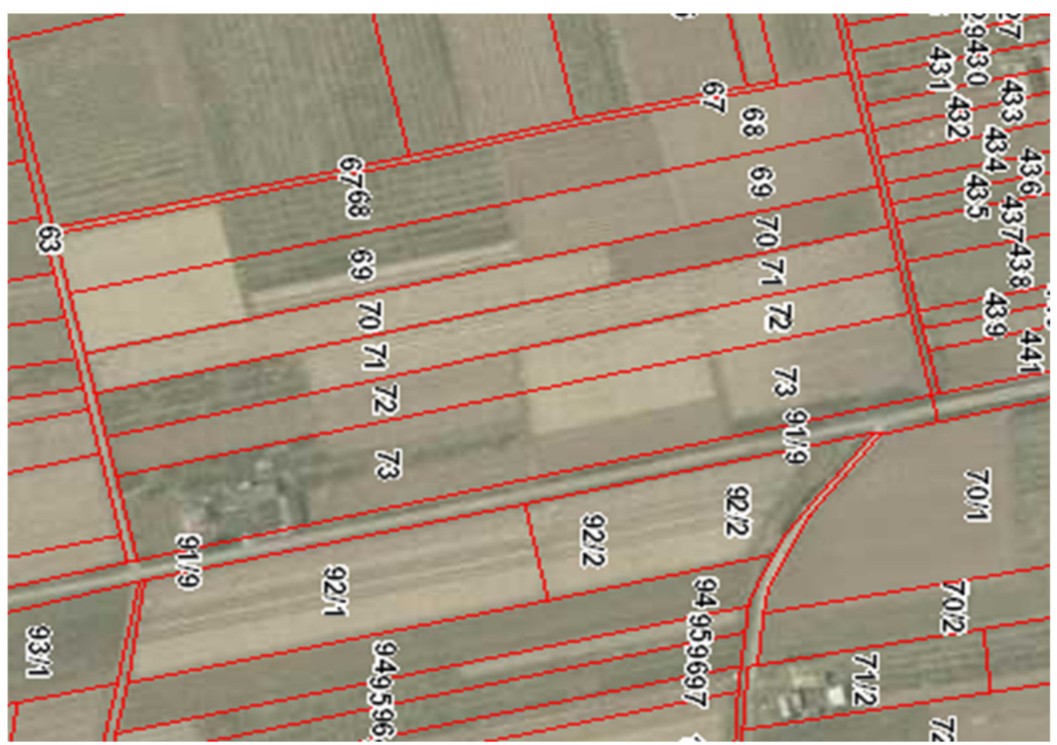

Figure 1. Plan of plots for hop cultivation on farm A $(71,72,73)$.

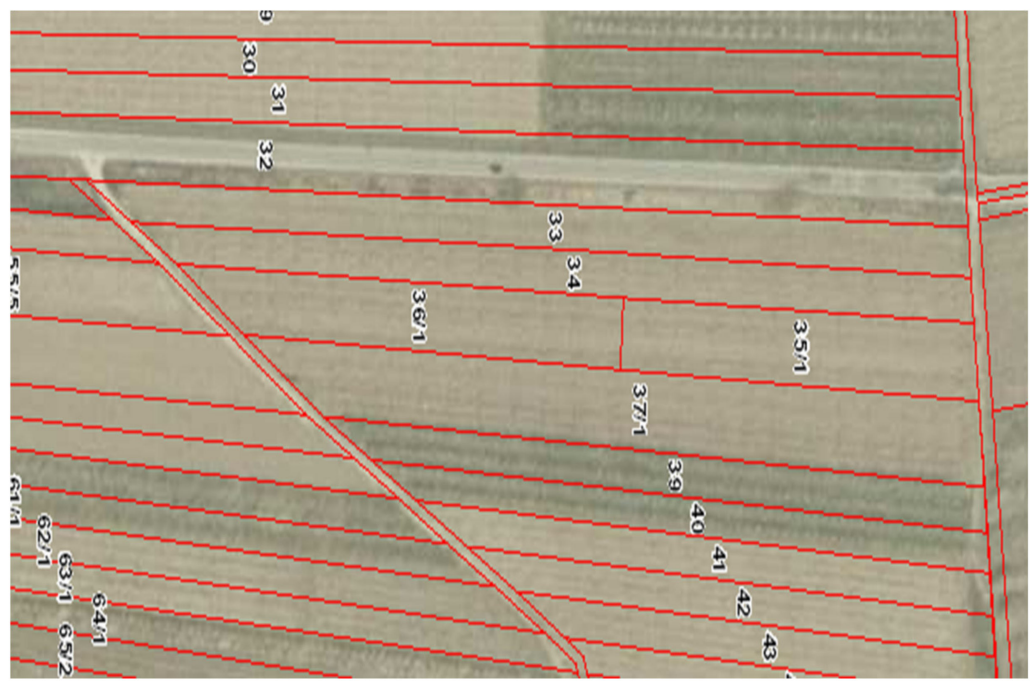

Figure 2. Plan of plots for hop cultivation on farm A $(71,72,73)$. 


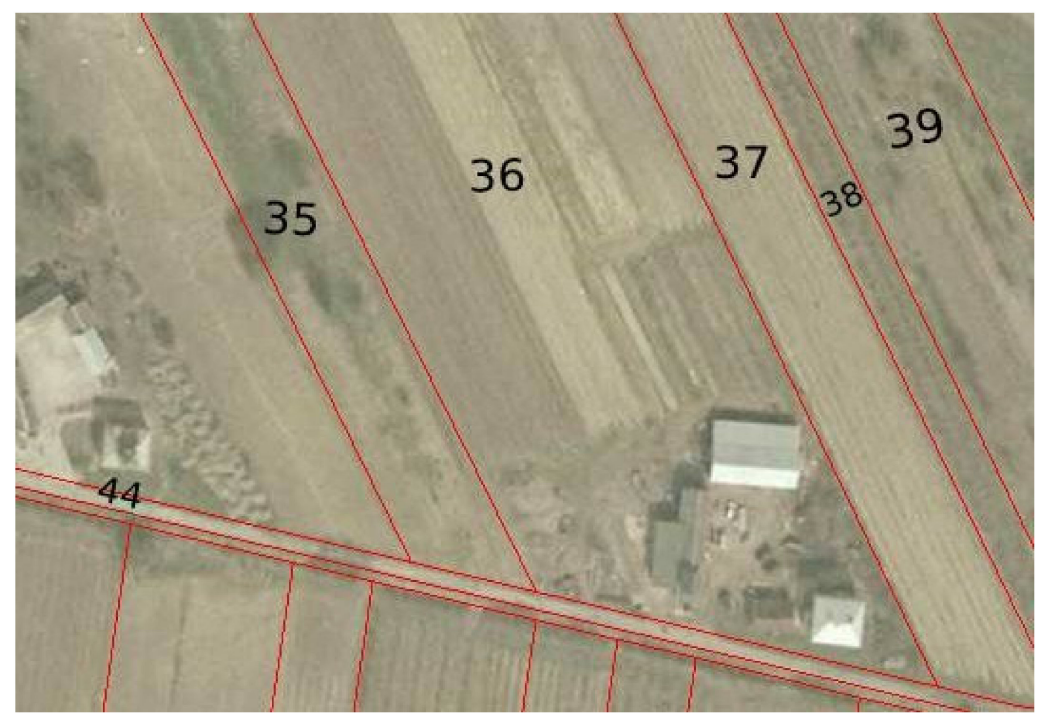

Figure 3. Plan of plots for hop cultivation at farm C (plots 36, 37, 38).

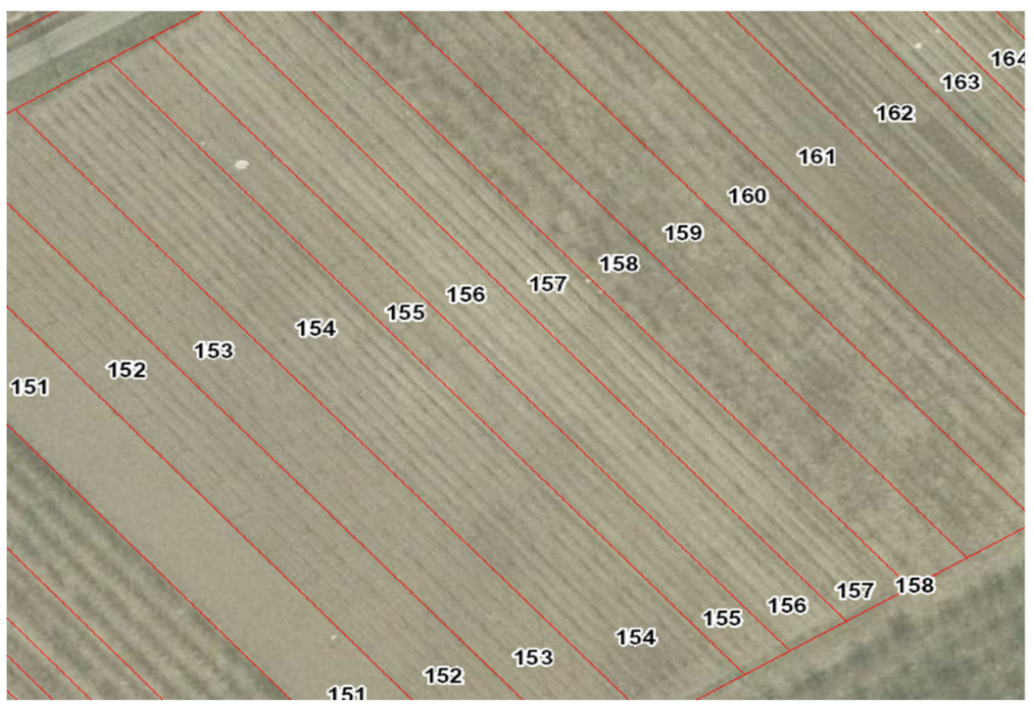

Figure 4. Plan of plots for hop cultivation at farm D (plots 155, 156, 157).

The plot was a row of 24 hop plants. The length of the plot was $38.4 \mathrm{~m}$, width $2.6 \mathrm{~m}$, and the harvested area was $98.4 \mathrm{~m}^{2}$. Plants were grown in a fork system, placing 2 shoots on two guides. The height of the structure was $7 \mathrm{~m}$. The material for setting up the experiment were healthy, rooted cuttings grown in the Plant Breeding and Biotechnology Department of IUNG, using modern biotechnological methods. The experiments were carried out as a typical production plantation, considering all the plant care and protection treatments.

\subsection{Characteristic of Varieties}

\subsection{1. 'Marynka'}

The bitter variety was created from the crossing of the Brewers Gold $x$ variety with wild hops, male, from the former Yugoslavia. Registration year 1988 (Table 2). A plant with a cylindrical-conical structure. The stem is green, with little foliage. The first shoots, the yielding ones, are embedded about $60 \mathrm{~cm}$ above the soil surface. It is a variety with a very good ability to guide guides and very good suitability for mechanical harvesting $\left(9^{\circ}\right.$ on a $9^{\circ}$ scale). Light green cones, approx. $3 \mathrm{~cm}$ long, ovoid in shape. The leaves are adhering, arranged very tightly on the ring in the cone. Hop flavor is intense [12,14]. 
Table 2. The status of hop varieties and their origin.

\begin{tabular}{|c|c|c|c|c|c|}
\hline No. & Varieties & Variety Registration Status * & The Origin of Varieties & The Origin of the Seedlings ** & $\begin{array}{c}\text { Year of Entry into the } \\
\text { Register of Original Varieties }\end{array}$ \\
\hline 1 & 'Marynka' & Bitter variety, Ro & $\begin{array}{l}\text { Was created in Poland from the } \\
\text { crossing of the Brewers Gold x } \\
\text { variety with wild hops, male } \\
\text { from the former Yugoslavia }\end{array}$ & IUNG & 1988 \\
\hline 2 & 'Iunga' 1 & Bitter variety, Ro & $\begin{array}{l}\text { Was created in Poland from the } \\
\text { crossing of 'Northern Brewer' } \times \\
\text { 'Marynka' varieties }\end{array}$ & IUNG & 2005 \\
\hline 3 & 'Magnum' & Bitter variety, Ro & $\begin{array}{l}\text { Was developed at the Hop } \\
\text { Research Center in Huell, } \\
\text { Germany. Her lineage consists of } \\
\text { a combination of Galena (the } \\
\text { American super-alpha variety) } \\
\text { and a male German variety } \\
\text { marked only with the } \\
\text { number } 75 / 5 / 3 \text {. }\end{array}$ & IUNG & 2000 \\
\hline 4 & 'Lubelski' & Super aromatic, Ro & $\begin{array}{l}\text { Was bred in Poland by individual } \\
\text { and pedigree selection from the } \\
\text { domestic population }\end{array}$ & IUNG & 1964 \\
\hline 5 & 'Sybilla' & Aromatic, Ro & $\begin{array}{c}\text { Was created in Poland by } \\
\text { crossing the 'Lubelski' variety } \\
\text { with wild male hops from the } \\
\text { former Yugoslavia }\end{array}$ & IUNG & 1996 \\
\hline 6 & 'Lomik' & Aromatic Rs & $\begin{array}{l}\text { Was created in Poland after } \\
\text { crossing the 'Northern Brewer' } \\
\text { variety with wild male hops from } \\
\text { the vicinity of Lublin and } \\
\text { subjected to the action of } \\
\text { mutagenic agents }\end{array}$ & POWIŚLE & 1988 \\
\hline
\end{tabular}

${ }^{*}$ Ro-varieties from the Varieties Register, Rs—selected; ${ }^{* *}$ IUNG—Institute of Cultivation and Fertilization-National Research Institute in Puławy, Department of Plant Breeding and Biotechnology, Poland; POWIŚLE_Powiśle General Partnership Company, Kępa Chotecka; 1-variety protected by the exclusive right of the breeder.

\subsection{2. 'Iunga'}

Bitterness variety, created from the crossing of 'Northern Brewer' $x$ 'Marynka' varieties, bred at the Institute of Soil Science and Plant Cultivation in Puławy, registered in 2005 (Table 2). It is characterized by a cylindrical structure. Very long, non-breakable side shoots with medium foliage. The first yielding shoots begin at a height of $100 \mathrm{~cm}$ from the soil. The variety is very suitable for mechanical harvesting ( 9 on the $9^{\circ}$ scale). Light yellow, elliptical cones, average size approx. $3 \mathrm{~cm}$. Perianth and flower leaves are closely arranged on the cone. The smell is very intense [12].

\subsection{3. 'Magnum'}

High bitter variety, bred in 1980 in Germany (Table 2). The plant is cylindrical and rapidly growing. Green stem, medium long side shoots, and large foliage. The first yielding shoots are placed at a height of $70 \mathrm{~cm}$ from the soil surface. Cones are evenly distributed over the plant. Cultivar with good ability to guide guides and very good suitability for mechanical harvest $\left(9^{\circ}\right.$ on a $9^{\circ}$ scale) and high resistance to fungal diseases. Dark green cones with a prismatic-conical shape and an intense smell. The leaves of the cone are closely arranged on the settlement [12].

\subsection{4. 'Lubelski'}

A super-aromatic variety, developed through individual and pedigree selection from the national population. Year of registration 1964 (Table 2). A plant with a cylindrical-clubshaped structure. Red-green stem. Long, brittle side shoots, medium foliage. The first yielding shoots begin at a height of $100 \mathrm{~cm}$ above the soil. The variety is moderately useful for mechanical harvest $\left(6^{\circ}\right.$ on a $9^{\circ}$ scale), with an average ability to guide the guides. Light yellow cones, average size about $4 \mathrm{~cm}$, conical shape, slightly flattened. A noble, delicate, very pleasant aroma of cones [12,14]. 


\subsection{5. 'Sybilla'}

The aromatic variety was created by crossing the 'Lubelski' variety with wild male hops from the former Yugoslavia. Year of registration 1996 (Table 2). A plant with a cylindrical structure. Green and red stalk with stripes. Long, non-breakable side shoots begin to yield at a height of $70 \mathrm{~cm}$ above the soil surface. Variety with very good suitability for mechanical harvesting ( 9 on a $9^{\circ}$ scale). Sensitive to powdery mildew. Light green, conical, elongated cones, approx. $4 \mathrm{~cm}$ long. The leaves of the perianth and flower cover fit tightly to each other. The smell is pleasant, harmonious, and mild [12].

\subsection{6. 'Lomik'}

The aromatic variety was created after crossing the 'Northern Brewer' variety with wild male hops from the vicinity of Lublin and subjected to the action of mutagenic agents. Registered in 1988 (Table 2). A plant with a cylindrical structure, red-purple stems. Long shoots, yielding from a height of $60 \mathrm{~cm}$ above the ground. This variety is good for guides, and suitable for mechanical harvesting $\left[7^{\circ}\right.$ on a $9^{\circ}$ scale]. Yellow-green, medium-sized, oval cones. The leaves are adherent, quite loosely arranged, on a delicate and regular base. Pleasant and mild aroma of cones [12].

\subsection{Field Research}

The hop fields in all localities were kept in high culture. Mineral fertilization was established based on the results of the Regional Chemical and Agricultural Station in Lublin. Mineral fertilization was carried out on three dates. The first date of NPK fertilization was in mid-March, and the fertilizers were applied in the amount of: N $60 \mathrm{~kg}$; P $40 \mathrm{~kg}$ and $\mathrm{K} 75 \mathrm{~kg} \mathrm{ha}^{-1}$. The second application date for mineral fertilizers was at the beginning of June. The following amounts of fertilizers were applied: $50 \mathrm{~kg} \mathrm{~N}, \mathrm{P}-30 \mathrm{~kg}, \mathrm{~K}-60 \mathrm{~kg} \mathrm{ha}^{-1}$. The third date of introducing mineral fertilizers was just before the flowering of hops, at the end of July, NPK was applied in the amount of: $40 \mathrm{~kg} \mathrm{~N}, 20 \mathrm{~kg} \mathrm{P}$ and $50 \mathrm{~kg} \mathrm{~K} \mathrm{ha}^{-1}$.

Downy mildew was observed on hop plants only in locality A. After directing the shoots to the guides, the systemic preparation Aliette WG (aluminum fosetyl) was used. This treatment was then repeated after 14 days and after the hops the grid level had reached. This disease, after performing plant protection treatments, did not cause any significant losses. Downy mildew appeared only on the "Marynka" variety before passaging. In the case of the cultivars: 'Magnum', 'Sybilla' and 'Lomik', the biggest problem in cultivation was the plum-hop aphid (Phorodon humuli Schrank), the greatest intensity of which took place before the hop flowering. The agents that were used to combat it are: Confidor 200 SL, Imidor 200 SL and Sherpa 100 EC (Table 3). Treatments were carried out several times, in accordance with the recommendations of the Institute of Plant Protection and the withdrawal period of these insecticides. The occurrence of other diseases and pests did not pose a threat to the hop plantation. The estimated hop growing area was divided into plots (Figures 1-4). 
Table 3. Plant protection treatments used in the cultivation of hops (2015-2017).

\begin{tabular}{|c|c|c|c|c|}
\hline No & Trade Name & Active Substance/ Composition & Preparation/ Doses & The Use/Terms \\
\hline 1 & Aliette $80 \mathrm{WG}$ & (Aluminum fosetyl) & $250 \mathrm{~g}$ in $100 \mathrm{dm}^{3} \mathrm{H}_{2} \mathrm{O}$ & $\begin{array}{l}\text { Against downy mildew } \\
\text { (Pseudoperonospora humuli) } \\
\text { immediately after being brought } \\
\text { onto the conductors in } 600 \mathrm{dm}^{3} \\
\mathrm{H}_{2} \mathrm{O} \mathrm{ha}^{-1} \text {, after two to } \\
3 \text { weeks-in } 800 \mathrm{dm}^{3} \mathrm{H}_{2} \mathrm{O} \text { ha }^{-1} \text {; } \\
\text { after the hops have reached the } \\
\text { grid level of } \\
1500-2000 \mathrm{dm}^{3} \mathrm{H}_{2} \mathrm{O} \mathrm{ha}^{-1}\end{array}$ \\
\hline 2 & $\begin{array}{l}\text { Confidor } 200 \text { SL, } \\
\text { Imidor } 200 \text { SL } \\
\text { Sherpa } 100 \text { EC }\end{array}$ & $\begin{array}{l}\text { Imidachlopryd } \\
\text { Imidaklopryd } \\
\text { cypermetryna }\end{array}$ & $\begin{array}{c}0.018 \% \mathrm{ha}^{-1} \\
0.018 \% \mathrm{ha}^{-1} \\
0.05 \% \mathrm{ha}^{-1}\end{array}$ & $\begin{array}{l}\text { Against the plum-hop aphid } \\
\text { (Phorodon humuli Schrank). } \\
\text { Plants were sprayed after } \\
\text { reaching the height of the } \\
\text { supporting structure } 3 / 4 \text {, the } \\
\text { treatment was repeated until the } \\
\text { cones matured. } \\
2000 \mathrm{dm}^{3} \mathrm{H}_{2} \mathrm{O} \text { ha }-1 \text { were used } \\
\text { for spraying after the mesh had } \\
\text { grown through }\end{array}$ \\
\hline
\end{tabular}

Crop rotation was applied in each locality. It was a three-field cultivation (Table 4).

Table 4. Crop rotation on the farm in 2011-2013.

\begin{tabular}{ccccc}
\hline \multirow{2}{*}{ Location * } & Plot Number & \multicolumn{3}{c}{ Years } \\
\cline { 3 - 5 } & & $\mathbf{2 0 1 1}$ & $\mathbf{2 0 1 2}$ & $\mathbf{2 0 1 3}$ \\
\hline A & $71,72,73$ & Rye & Phacelia & Turnip \\
B & $33,34,35$ & Phacelia & White mustard & Rye \\
C & $36,37,38$ & Turnip & Rye & White mustard \\
D & $155,156,157$ & Turnip & Rye & White mustard \\
\hline
\end{tabular}

* designations of localities as in Table 1.

In all localities, catch crops were used for plowing in as green fertilizer. The collection of cones was carried out manually, in the $89 \mathrm{BBCH}$ phase, when the cones were well-formed, closed and had a golden-green color, and after opening the leaves, lemon-yellow lupulin balls were visible. The cones were also characterized by a specific aroma. Within $6 \mathrm{~h}$ after picking, the cones were dried at a temperature of $60{ }^{\circ} \mathrm{C}$.

The text continues here (Figures 1-4).

\subsection{Collection and Determination of Soil Samples}

Every year, before spring fertilization, 20 primary soil samples were collected, making up one general sample, weighing $0.5 \mathrm{~kg}$ [17]. The chemical and physicochemical properties of the soil were determined in a certified laboratory of the Regional Chemical and Agricultural Station in Lublin (Scope of accreditation No. AB 1186) using the following methods: soil granulometric composition by laser diffraction [18,19]; reaction: $\mathrm{pH}$ in $1 \mathrm{M}$ $\mathrm{KCl}$-electrometrically [20]; organic carbon content- $\mathrm{C}_{\text {org }}$ - - the Tiurin method [21] and on its basis the humus content in the soil was determined [22]; absorbable magnesium content by the Schachtschabel method [23]; content of available forms of phosphorus and potassium (Egner-Riehm method) [24,25]; content of $\mathrm{Cu}, \mathrm{Mn}, \mathrm{Zn}, \mathrm{Fe}$ in 1 mol of HCl-by the ASA method [26-28]; and B content-spectrophotometrically with curcumin [29].

\subsection{Sampling of Hop Cones}

The full qualitative assessment of the cones consisted of the following analyses: mechanical-physical and chemical. The sample consisted of the number of cones of 
equal size, collected in 5-10 places of a pile of cones, from the surface, as well as from different depths. The sample was placed in the container as quickly as possible. In order to avoid a quick deterioration of the quality of the samples, the number of hops was collected in such a quantity that when closing the container, it was strongly crushed. The sample weight was not less than $250 \mathrm{~g}$ [30].

\subsection{Mechanical Analysis of Cones}

Mechanical analysis of the hop cones was carried out directly after the harvest. The assessment of morphological parameters concerned such features as: the length of the cones $(\mathrm{cm})$, number of nodes per cone spindle of hop, the compactness of the cones, the weight of 100 cones. Moreover, the interdependencies between them were determined. Two qualitative indicators were calculated: the cone compactness index and the cone specific weight index:

$$
\begin{aligned}
& \text { Hop cone density indicator }=\frac{\text { the number of kinks hop cones }}{\text { length of cone spindle of hop in } \mathrm{mm}} \\
& \text { Indicator of the specific weight of cones }=\frac{\text { weight of } 100 \text { cones in } \mathrm{g}}{\text { The length of the hop rachis in } \mathrm{mm}}
\end{aligned}
$$

The dried cones were counted, weighed on an electronic balance and then their parameters were measured with an analog caliper. In the test of cones, the covering leaves were torn off and then the cone length, the length of cone spindle of hop was measured, and the number of its bends was counted. The length of cones, and the number of refractions was the average of the measurement of 100 cones for each repeat, each variety and location $[12,14]$.

\subsection{Chemicals Analysis}

In the years 2015-2017, a comprehensive qualitative assessment of the raw material obtained from the experience was carried out. In addition to standard analyzes of the content of resins in cones carried out using the Wöllmer method, for all varieties and localities, analyzes of the compounds constituting the hop aroma were also carried out. In order to determine alpha- and beta-acids, mean samples were taken at plantations. After drying, these samples were mixed, milled and only a $50 \mathrm{~g}$ sample from each locality, cultivar and each replication of the field experiment was taken for analysis. The weight was transferred to the vessel and mixed with $20 \mathrm{~mL}$ of methanol $\left(\mathrm{CH}_{3} \mathrm{OH}\right), 100 \mathrm{~mL}$ of diethyl ether $\left[\left(\mathrm{C}_{2} \mathrm{H}_{5}\right)_{2} \mathrm{O}\right]$ and $40 \mathrm{~mL}$ of $0.1 \mathrm{~N} \mathrm{HCl}$. After shaking thoroughly, this solution was allowed to stand for approximately one hour until the layers separated. After this time, the $5 \mathrm{~mL}$ ether layer was transferred to a $50 \mathrm{~mL}$ volumetric flask and made up with methanol. After these operations, the sample was ready for liquid chromatography testing. Alpha- and beta-acids were determined by liquid chromatography, and hop oils by gas chromatography. The carrier of the device was the eluent (a liquid eluting substances adsorbed on the solid phase during chromatography), i.e., a mixture of methanol, water, and phosphoric acid. After sampling by the device, the sample was mixed with the eluent, and then went to the separator, which separated the substances into individual fractions. The samples were then passed through a light detector, which reads the temporal separation of the peaks. The obtained graphs were compared with the standard of pure alpha- and beta-acids substances and the results were read. Each action was performed in accordance with Polish Standards [31].

\subsubsection{Determination of Hop Resins}

Deryng's steam distillation apparatus was used to extract all hop oils. The sample preparation was carried out in the same way as in the case of testing the content of alphaand beta-acids. First, $50 \mathrm{~g}$ of hop cones were very finely ground, and $300 \mathrm{~g}$ of water was added, while thoroughly mixing them. The mixture prepared in this way was placed in 
the distiller. The distillation consisted in supplying the sample with water vapor, which heated it and caused the water and hop oils to evaporate, leaving the remains of ground cones in the flask. The volatilized oils and water then went to the cooler, where they were cooled, and the liquid condenses. In the receptacle where the substance is collected, the hop oils were separated from the water. The quantity of oils obtained was the total value contained in a given sample of hop cones [31].

\subsubsection{GC Analysis of Essential Oils from Hops}

The identification and quantification of hops oil components was performed according to Analytica Method EBC 7.10 [32,33]. First, $50 \mathrm{~g}$ of dry and ground hop cones were mixed with $1000 \mathrm{~mL}$ of deionized water and distilled steam for $3 \mathrm{~h}$. Next, $0.2 \mathrm{~mL}$ of the oil collected was diluted with $5 \mathrm{~mL}$ of hexane and separated by GC analysis. The GC Agilent 6890 system was equipped with a flame ionization detector and HP-1 capillary column (30 m $\times 0.25 \mathrm{~mm}, 25 \mu \mathrm{m}$, Agilent, San-ta Clara, CA, USA) and nitrogen 5.0 as carrier gas with a flow rate of $0.6 \mathrm{~mL} \mathrm{~min}^{-1}$. Then, $1 \mu \mathrm{L}$ of the test solution was injected into the injector at $200{ }^{\circ} \mathrm{C}$. The programmed time was $1 \mathrm{~min}$ at $60^{\circ} \mathrm{C}, 2.5^{\circ} \mathrm{C} \mathrm{min}{ }^{-1}$ to $190{ }^{\circ} \mathrm{C}, 1 \mathrm{~min}$ at $190{ }^{\circ} \mathrm{C}, 70{ }^{\circ} \mathrm{C} \mathrm{min}^{-1}$ to $240{ }^{\circ} \mathrm{C}$ and $11 \mathrm{~min}$ at $240{ }^{\circ} \mathrm{C}$. Detection was performed on a flame ionization detector at a temperature of $260{ }^{\circ} \mathrm{C}$ [34]. All solvents were of analytical purity or higher and were supplied from Sigma-Aldrich, Germany. The main components of oils have been marked, such as: myrcene, beta-caryophyllene, alpha-humulene, farnesene, caryophyllene epoxide, humulene-2 epoxide, humulene-epoxide, farnesol, and others. The LOQ of the method was $0.1 \%$ relative. Only the main components of essential oils are included in the work.

\subsection{Research Conditions}

\subsubsection{Natural Conditions}

The research was carried out within the limits of the Małopolska Gorge of the Vistula. It is the largest hop-growing region in Poland. The region of the Małopolski Poland Vistula Gorge is about $80 \mathrm{~km}$ long and is located between Annopol and Puławy (Figure 5). The width of this area is $1.5-10 \mathrm{~km}$, which gives a total area of about $300 \mathrm{~km}^{2}$ [35].

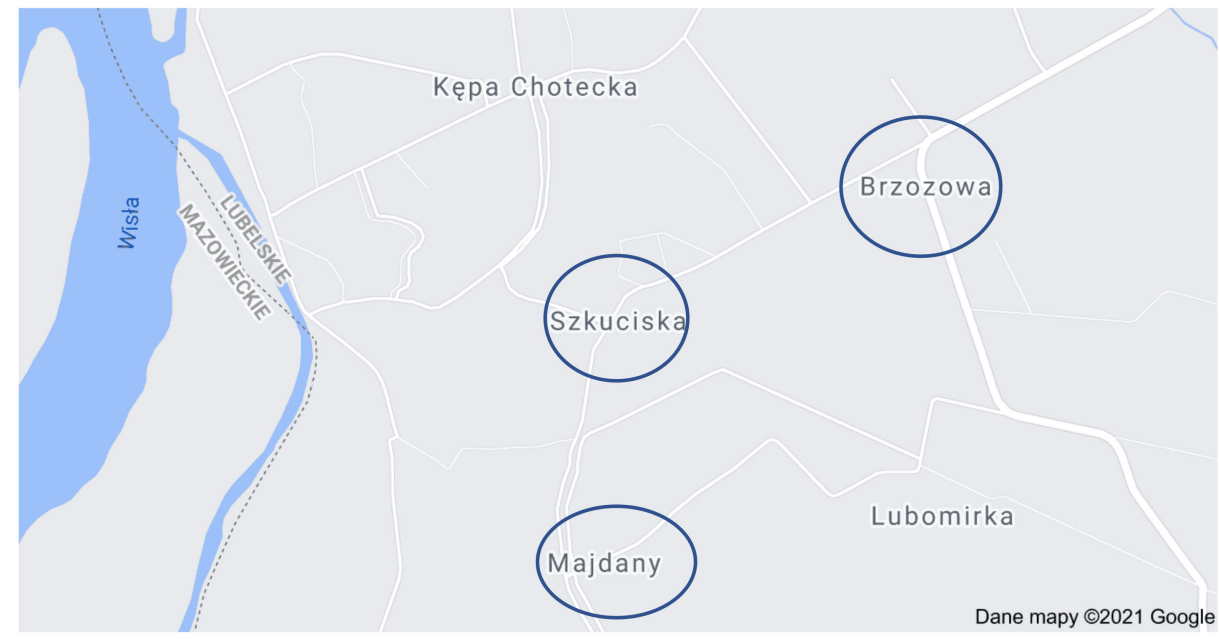

Figure 5. Research location.

In this area, there are chalk rendzinas, light and medium dumps made of tilts, heavy soils from various clays. The Vistula in this section descends from $135 \mathrm{~m}$ above sea level to $115 \mathrm{~m}$ above sea level, which is the lowest gorge point. This region is characterized by a moderately continental, somewhat humid and harsh climate. In the region of the Małopolski Poland Vistula Gorge, there may be days with hot weather, in which the daily temperature exceeds $25^{\circ} \mathrm{C}$. However, the average annual air temperature fluctuates around 
$7{ }^{\circ} \mathrm{C}$. In this area, sunny days are more numerous than overcast days without rainfall. The region of the Małopolski Poland Vistula Gorge, compared to other regions, is characterized by a large number of very warm, overcast days, with no rainfall. There are 8 frosty days with rainfall and 18 days without rainfall. Average annual rainfall in this region ranges between 600-650 $\mathrm{mm}$ [36].

\subsubsection{Soil Conditions}

The grain size composition allows it to be classified as medium soils [37] (Tables 5 and 6).

Table 5. Soil granulometric composition (2015-2017).

\begin{tabular}{ccccc}
\hline Location * & \multicolumn{3}{c}{ Percentage of Fraction Diameter $(\mathbf{m m} \varnothing)$} & $\begin{array}{c}\text { Composition Granulometric } \\
\text { (acc. Usda) }\end{array}$ \\
\cline { 2 - 4 } & $\mathbf{0 . 5 - 2 . 0}$ & $\mathbf{0 . 5 - 0 . 0 0 2}$ & $<\mathbf{0 . 0 0 2}$ & SiL \\
\hline Zastów & 36.97 & 57.06 & 5.97 & $\mathrm{SiL}^{* *}$ \\
Szkuciska & 34.47 & 59.21 & 6.32 & $\mathrm{SiL}$ \\
Brzozowa & 36.78 & 58.01 & 5.21 & $\mathrm{SiL}$ \\
Majdany & 36.41 & 57.09 & 6.50 & $\mathrm{SiL}$ \\
\hline Average & 36.16 & 57.84 & 5.49 & \\
\hline
\end{tabular}

*SiL—silty loam; Source: own study based on the results of the Regional Chemical and Agricultural Station in Lublin.

Table 6. Content of available forms of $\mathrm{P}_{2} \mathrm{O}_{5}, \mathrm{~K}_{2} \mathrm{O}, \mathrm{Mg}, \mathrm{B}, \mathrm{Mn}, \mathrm{Cu}, \mathrm{Zn}, \mathrm{Fe}$, humus, $\mathrm{C}_{\text {org }}$ in the soil and soil acidity (Mean 2015-2017).

\begin{tabular}{|c|c|c|c|c|c|c|c|c|c|c|c|}
\hline \multirow[t]{2}{*}{ Location } & \multicolumn{3}{|c|}{$\begin{array}{l}\text { Content of Assimilable } \\
\text { Forms of Elements } \\
\text { [mg } 100 \mathrm{~g}^{-1} \text { of Soil] }\end{array}$} & \multirow[t]{2}{*}{$\begin{array}{l}\text { Humus } \\
{\left[\mathrm{gkg}^{-1}\right]}\end{array}$} & \multirow[t]{2}{*}{$\begin{array}{l}\text { Content } \\
\text { Corg }_{\text {org }}\end{array}$} & \multirow[t]{2}{*}{$\begin{array}{c}\mathrm{pH}[1 \\
\mathrm{mol} \mathrm{KCI}]\end{array}$} & \multicolumn{5}{|c|}{$\begin{array}{l}\text { The Content of Micronutrients } \\
\text { [mg kg } \mathrm{kg}^{-1} \text { soil] }\end{array}$} \\
\hline & $\mathrm{P}_{2} \mathrm{O}_{5}$ & $\mathrm{~K}_{2} \mathrm{O}$ & $\mathbf{M g}$ & & & & B & Mn & $\mathrm{Cu}$ & $\mathrm{Zn}$ & $\mathrm{Fe}$ \\
\hline Zastów & 26.9 & 11.6 & 19.5 & 2.67 & 1.37 & 7.3 & 3.85 & 295 & 57.5 & 24.5 & 3630 \\
\hline Szkuciska & 10.9 & 9.6 & 10.3 & 2.82 & 1.29 & 5.9 & 1.44 & 233 & 58.0 & 16.4 & 2755 \\
\hline Brzozowa & 13.1 & 11.1 & 10.9 & 2.51 & 1.34 & 6.9 & 2.97 & 248 & 42.5 & 18.4 & 2245 \\
\hline Majdany & 27.3 & 12.0 & 20.6 & 2.67 & 1.36 & 7.1 & 4.02 & 299 & 60.1 & 25.5 & 3690 \\
\hline
\end{tabular}

Valuation according to limit numbers for hops carried out by the Regional Chemical-Agricultural Station in Lublin.

In the analyzed localities, there were mineral soils with a granulometric composition of clayey loam (Table 5). Considering the content of available forms of phos-

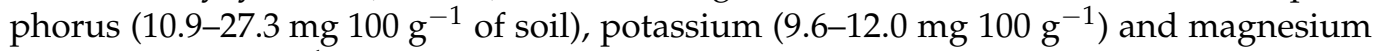
(9.6-12.0 mg $100 \mathrm{~g}^{-1}$ ), these soils should be classified as average and rich in phosphorus, low in potassium and high to very high in magnesium. The soil reaction ranged from slightly acidic to alkaline (Table 6).

The content of assimilable forms of micronutrients soluble in 1 mole of $\mathrm{HCl}$ was in the following ranges: $\mathrm{B}-1.44-4.02 \mathrm{mg} \mathrm{kg}^{-1}, \mathrm{Cu}-42.5-60.1 \mathrm{mg} \mathrm{kg}^{-1}, \mathrm{Mn}-233-299 \mathrm{mg} \mathrm{kg}^{-1}$, $\mathrm{Zn}-16.4-25.5 \mathrm{mg} \mathrm{kg}^{-1}$, and Fe-2245-3690 $\mathrm{mg} \mathrm{kg}^{-1}$ (Table 6). These values indicated a low to high abundance of assimilable boron, medium to high abundance in manganese, high to very high abundance in copper, low abundance in zinc and medium abundance in assimilable iron [38].

\subsubsection{Meteorological Conditions}

The course and distribution of precipitation and air temperatures during the growing season of the hop varied. The Sielianinov (K) hydrothermal coefficient [39] (Table 7) was used to determine dry periods. 
Table 7. The sum and distribution of rainfall and average air temperature during the growing season of hop in the years 2014-2017 according to the meteorological station in Felin.

\begin{tabular}{|c|c|c|c|c|c|c|c|c|c|c|}
\hline \multirow{3}{*}{ Year } & \multirow{3}{*}{ Month } & \multirow{2}{*}{\multicolumn{3}{|c|}{$\begin{array}{c}\begin{array}{c}\text { Total Rainfall } \\
\text { a Month (mm) }\end{array} \\
\text { Decade of Month }\end{array}$}} & \multirow{3}{*}{$\begin{array}{l}\text { Total Rainfall } \\
\text { a Month (mm) }\end{array}$} & \multirow{2}{*}{\multicolumn{3}{|c|}{$\begin{array}{c}\begin{array}{c}\text { Average Air } \\
\text { Temperature }\left({ }^{\circ} \mathrm{C}\right)\end{array} \\
\text { Decade of Month }\end{array}$}} & \multirow{3}{*}{$\begin{array}{l}\text { Average Air } \\
\text { Temperature in the } \\
\text { Month }\left({ }^{\circ} \mathrm{C}\right)\end{array}$} & \multirow{3}{*}{$\begin{array}{c}\text { Sielianinov } \\
\text { Hydrotherma } \\
\text { Coefficient }\end{array}$} \\
\hline & & & & & & & & & & \\
\hline & & 1 & 2 & 3 & & 1 & 2 & 3 & & \\
\hline \multirow{7}{*}{2014} & April & 3.2 & 15.3 & 26.2 & 44.7 & 7.4 & 7.9 & 14.1 & 9.8 & 1.5 \\
\hline & May & 32.7 & 88.4 & 72.5 & 193.6 & 10.6 & 12.9 & 17.4 & 13.6 & 4.6 \\
\hline & June & 11.2 & 3.0 & 63.9 & 78.1 & 17.4 & 16.0 & 15.4 & 16.3 & 1.6 \\
\hline & July & 14.2 & 38.4 & 30.6 & 83.2 & 19.4 & 19.8 & 21.8 & 20.3 & 1.3 \\
\hline & August & 24.9 & 32.8 & 44.5 & 102.2 & 22.5 & 18.1 & 14.4 & 18.3 & 1.8 \\
\hline & September & 3.2 & 2.7 & 19.3 & 25.2 & 15.3 & 15.4 & 11.2 & 14.0 & 0.6 \\
\hline & Sum & & & & 527.0 & & & & & 2.2 \\
\hline \multirow{7}{*}{2015} & April & 12.7 & 2.8 & 25.3 & 40.8 & 4.5 & 8.6 & 13.2 & 8.7 & 1.6 \\
\hline & May & 26.8 & 8.9 & 76.2 & 111.9 & 13.5 & 13.2 & 13.1 & 13.3 & 2.7 \\
\hline & June & 0.8 & 8.1 & 3.2 & 12.1 & 18.6 & 17.7 & 16.8 & 17.7 & 0.2 \\
\hline & July & 9.4 & 23.5 & 10.7 & 43.6 & 23.0 & 20.8 & 21.8 & 21.9 & 0.6 \\
\hline & August & 0.0 & 0.0 & 7.6 & 7.6 & 27.4 & 23.9 & 22.1 & 24.4 & 0.1 \\
\hline & September & 37.7 & 32.2 & 42.8 & 112.7 & 15.4 & 17.6 & 13.1 & 15.3 & 2.5 \\
\hline & Sum & & & & 328.7 & & & & & 1.3 \\
\hline \multirow{7}{*}{2016} & April & 14.0 & 13.6 & 16.4 & 44.0 & 10.7 & 10.6 & 7.9 & 9.7 & 1.5 \\
\hline & May & 14.2 & 21.6 & 2.1 & 37.9 & 13.6 & 12.2 & 19.2 & 15.1 & 0.8 \\
\hline & June & 5.5 & 35.5 & 2.4 & 43.4 & 17.0 & 18.2 & 22.4 & 19.2 & 0.8 \\
\hline & July & 13.7 & 49.8 & 66.2 & 129.7 & 18.9 & 18.7 & 22.0 & 19.9 & 2.1 \\
\hline & August & 28.2 & 5.9 & 37.3 & 71.4 & 19.8 & 16.8 & 19.6 & 18.8 & $\begin{array}{l}2.1 \\
1.2\end{array}$ \\
\hline & September & 7.4 & 0.0 & 3.7 & 11.1 & 19.2 & 16.3 & 12.1 & 15.8 & 0.2 \\
\hline & Sum & & & & 337.5 & & & & & 1.1 \\
\hline \multirow{6}{*}{2017} & April & 8.9 & 20.3 & 21.9 & 51.1 & 7.0 & 7.5 & 9.8 & 8.1 & $\begin{array}{l}1.1 \\
2.1\end{array}$ \\
\hline & May & 39.2 & 28.9 & 33.5 & 101.6 & 11.8 & 14.2 & 17.9 & 15.3 & 2.1 \\
\hline & June & 42.1 & 53.2 & 10.6 & 105.9 & 17.8 & 19.6 & 18.1 & 18.5 & 1.9 \\
\hline & July & 49.3 & 56.7 & 20.1 & 126.1 & 19.6 & 18.4 & 19.6 & 19.2 & 2.1 \\
\hline & August & 0.0 & 9.5 & 8.3 & 17.8 & 20.5 & 19.1 & 18.0 & 19.2 & 0.3 \\
\hline & September & 28.2 & 16.3 & 20.1 & 64.6 & 14.3 & 11.1 & 10.0 & 11.8 & 1.8 \\
\hline
\end{tabular}

Source: own study according to data from the Institute of Meteorology and Water Management-National Research Institute, Felin meteorological station.

The following ranges of values for the Sielianinov coefficient were adopted: extremely dry $\mathrm{k} \leq 0.4$; very dry $-0.4<\mathrm{k} \leq 0.7$; dry- $0.7<\mathrm{k} \leq 1.0$; quite dry $-1.0<\mathrm{k} \leq 1.3$; optimal$1.3<\mathrm{k} \leq 1.6$; quite wet $-1.6<\mathrm{k} \leq 2.0$; wet $-2.0<\mathrm{k} \leq 2.5$; very humid-2.5 $<\mathrm{k} \leq 3.0$; extremely humid $-\mathrm{k}>3.0$ [39].

$\mathrm{K}=\frac{\mathrm{P}}{0.1 * \sum \mathrm{t}}$, where: K-value of the hydrothermal coefficient, P-sum of monthly precipitation, $\mathrm{t}$-sum of average daily air temperatures in a given month.

In the last two months of hop vegetation (July-August), air temperatures, especially in 2015, were extremely high, which could have had an impact on the proper process of plant vegetation, cone maturation and the formation of lupulin. September 2015 turned out to be a wet month (Table 7), which allowed us to create conditions for good preparation of plants before winter.

In 2016, the highest air temperatures were recorded during the entire research period, especially in April-June, which determine the growth and development of plants in spring. Precipitation in April was at an optimal level, but in May and June it was very low, which qualified these months as dry. In July, rainfall higher than the long-term average by about $40.0 \%$ was recorded, which allowed for the regeneration of plants after a drought and the formation of cones. August turned out to be quite dry, and September was extremely dry (Table 7).

The year 2017 was quite wet, especially the period from April to July was wet, but during the flowering of plants, in August there was an extreme drought, and despite its strong root system, it contributed to the weakening of cone formation (Table 7).

\subsection{Statistical Calculatons}

The results of the research were statistically processed, mainly by means of ANOVA [40]. The significance of the sources of variation was tested with the Fischer-Snedecor " $F$ " test, and the significance of differences between the compared means was assessed using multiple Tukey intervals [41]. In the case of detailed analyzes based on T-Tukey's tests, the significance level was $\alpha=0.05$. Letter indicators at the means (significant groups) define the so-called homogeneous (statistically homogeneous) groups. The presence of the same 
letter index with the means (at least one) means that there is no statistically significant difference between them. The subsequent letter indices $a, b$, etc. define the groups in ascending order. The empirical mean squares from the ANOVA were then compared with their expected values. The equations obtained in this way made it possible to estimate the variance components corresponding to individual sources of variability. The mutual dependencies between the evaluations of the variance components and their percentage structure were then the basis for the assessment of the impact of the studied varieties, years, and geographic location on the variability of the mechanical and chemical analysis of hop cones. The function parameters were determined by the least squares method. The percentage share of individual sources of variation and their interactions in the total variability of the studied features was determined by estimating the components of variance, where: $\sigma_{\mathrm{e}}{ }^{2}$ is an estimate of the environmental variability associated with the repetition of observations or measurements over time; $\sigma_{\mathrm{L}}^{2}$ is an estimate of the variability of geographic position (location); $\sigma_{\mathrm{p}}^{2}$ is an estimate of the (total) phenotypic variability [42].

\section{Results}

\subsection{The Yield of Fresh and Dry Mass of Cones}

The average yield of fresh hop cones in the analyzed localities, in 2015-2017, was at an average level and amounted to $16.91 \mathrm{t} \mathrm{ha}^{-1}$, and the dry weight yield of cones was $2.00 \mathrm{tha}^{-1}$ (Table 8 ).

Table 8. Fresh and dry yield of hop (H. lupulus L.) [t ha $\left.{ }^{-1}\right]$.

\begin{tabular}{|c|c|c|c|c|c|c|c|c|c|c|}
\hline \multirow{3}{*}{ Variety } & \multicolumn{5}{|c|}{ A Fresh Yield of Cones [t ha- $\left.a^{-1}\right]$} & \multicolumn{5}{|c|}{ A Dry Yield of Cones [ $\left.t \mathrm{ha}^{-1}\right]$} \\
\hline & \multicolumn{10}{|c|}{ Location * } \\
\hline & A & B & $\mathrm{C}$ & D & $X$ & $\mathbf{A}$ & B & $\mathrm{C}$ & D & $X$ \\
\hline 'Marynka' & $19.20^{\mathrm{a}^{* *}}$ & $16.67^{\mathrm{b}}$ & $19.60^{b}$ & $18.36^{\mathrm{b}}$ & $18.46^{\mathrm{b}}$ & $2.30^{\mathrm{a}}$ & $2.00^{b}$ & $2.34^{\mathrm{b}}$ & $2.35^{b}$ & $2.22^{b}$ \\
\hline 'Iunga' & $18.34^{\mathrm{a}}$ & $20.00^{a}$ & $22.90^{a}$ & $20.58^{a}$ & $20.46^{\mathrm{a}}$ & $2.20^{a}$ & $2.40^{\mathrm{a}}$ & $2.75^{a}$ & $2.75^{\mathrm{a}}$ & $2.45^{a}$ \\
\hline 'Magnum' & $15.80^{\mathrm{b}}$ & $19.60^{\mathrm{a}}$ & $20.00^{b}$ & $18.67^{b}$ & $18.52^{b}$ & $1.90^{\mathrm{b}}$ & $2.35^{\mathrm{a}}$ & $2.63^{\mathrm{a}}$ & $2.40^{b}$ & $2.22^{b}$ \\
\hline 'Lubelski' & $10.00^{c}$ & $8.34^{\mathrm{c}}$ & $10.80^{\mathrm{d}}$ & $9.91^{\mathrm{c}}$ & $9.76^{c}$ & $1.20^{c}$ & $1.00^{\mathrm{c}}$ & $1.29^{c}$ & $1.30^{\mathrm{d}}$ & $1.17^{\mathrm{c}}$ \\
\hline 'Sybilla' & $14.20^{\mathrm{b}}$ & $17.50^{\mathrm{b}}$ & $19.50^{b}$ & $17.92^{b}$ & $17.28^{b}$ & $1.70^{b}$ & $2.10^{b}$ & $2.56^{\mathrm{a}}$ & $2.35^{b}$ & $2.05^{b}$ \\
\hline 'Lomik' & $16.50^{\mathrm{b}}$ & $16.70^{b}$ & $16.70^{c}$ & $18.12^{b}$ & $17.00^{\mathrm{b}}$ & $1.82^{b}$ & $1.90^{\mathrm{b}}$ & $2.10^{b}$ & $1.90^{\mathrm{c}}$ & $1.87^{\mathrm{C}}$ \\
\hline Average & $15.67^{c}$ & $16.47^{b}$ & $18.25^{a}$ & $17.26^{b}$ & 16.91 & $1.85^{c}$ & $1.86^{\mathrm{c}}$ & $2.28^{a}$ & $2.18^{b}$ & 2.00 \\
\hline
\end{tabular}

${ }^{*}$ Designations of localities as in Table $1 .{ }^{* *}$ Letter indicators at the means (significant groups) define the so-called homogeneous (statistically homogeneous) groups. The presence of the same letter index with the means (at least one) means that there is no statistically significant difference between them. The subsequent letter indices $a, b$, etc., define the groups in ascending order.

The yields of fresh hop cones turned out to be significantly differentiated both between varieties, years and localities. The highest, average yield was obtained in locality $\mathrm{C}$, and the lowest in locality A. The difference in the value of this trait between villages B and D turned out to be insignificant. The 'Iunga' variety was the most fertile, and the least 'the' Lubelski 'variety. The varieties 'Marynka' and 'Magnum' as well as 'Sybilla' and 'Lomik' turned out to be homogeneous in this respect. In A locality, the 'Marynka' variety turned out to be the most prolific, while in B, C and D-'Iunga'. In locality B, homogeneous in terms of this feature, turned out to be: 'Marynka', 'Lomik' and 'Sybilla', while in C-'Marynka' and 'Sybilla', and in locality D—homogeneous were: 'Marynka', 'Magnum', 'Sybilla', and 'Lomik' (Table 7).

Dry matter yield of cones ranged from 1.00 to $2.75 \mathrm{t} \mathrm{ha}^{-1}$. The highest dry matter yield of cones was obtained in locality $\mathrm{C}$, significantly in locality $\mathrm{D}$, and the value of this characteristic in the locality A and B turned out to be homogeneous. The 'Lubelski' variety turned out to be the least fertile in all localities, and the most fertile in B, C and D localities was 'Iunga', and in the locality A - 'Marynka'. The 'Iunga' variety in locality A did not differ significantly from the 'Marynka' variety (Table 7). 


\subsection{A Dry and Fresh Mass of One Hundred Cones}

The highest weight of both fresh and dry 100 cones was obtained by the 'Magnum' variety, but the 'Sybilla' variety turned out to be homogeneous in terms of this feature. The lowest value of fresh and dry matter of 100 cones was obtained by the variety 'Lomik' (Table 9).

Table 9. Fresh and dry weight of 100 hop cones (average for 2015-2017).

\begin{tabular}{|c|c|c|c|c|c|c|c|c|c|c|}
\hline \multirow{3}{*}{ Varieties } & \multicolumn{5}{|c|}{ A Fresh Mass of 100 Cones [g] } & \multicolumn{5}{|c|}{ A Dry Mass of 100 Cones [g] } \\
\hline & \multicolumn{10}{|c|}{ Location * } \\
\hline & A & B & $\mathrm{C}$ & $\mathbf{D}$ & $X$ & $\mathbf{A}$ & B & $\mathrm{C}$ & D & $X$ \\
\hline 'Marynka' & $224.7^{b * *}$ & $214.6^{c}$ & $211.8^{c}$ & $215.3^{c}$ & $216.6^{c}$ & $27.0^{\mathrm{c}}$ & $25.2^{\mathrm{c}}$ & $24.4^{\mathrm{c}}$ & $27.5^{\mathrm{c}}$ & $26.0^{c}$ \\
\hline 'Iunga' & $224.6^{\mathrm{b}}$ & $210.9^{c}$ & $218.7^{b}$ & $229.0^{b}$ & $220.8^{b}$ & $26.6^{c}$ & $25.4^{\mathrm{c}}$ & $25.6^{\mathrm{b}}$ & $28.4^{b}$ & $26.5^{\mathrm{c}}$ \\
\hline 'Magnum' & $310.4^{\mathrm{a}}$ & $307.1^{\mathrm{a}}$ & $308.2^{\mathrm{a}}$ & $307.5^{a}$ & $308.3^{\mathrm{a}}$ & $37.1^{\mathrm{a}}$ & $36.4^{\mathrm{a}}$ & $37.9^{\mathrm{a}}$ & $36.6^{\mathrm{a}}$ & $37.0^{\mathrm{a}}$ \\
\hline 'Lubelski' & $238.2^{b}$ & $236.4^{b}$ & $226.7^{b}$ & $231.9^{b}$ & $233.3^{\mathrm{b}}$ & $29.6^{b}$ & $28.2^{b}$ & $26.3^{b}$ & $27.9^{b}$ & $28.0^{\mathrm{b}}$ \\
\hline 'Sybilla' & $306.1^{\mathrm{a}}$ & $302.0^{\mathrm{a}}$ & $303.0^{\mathrm{a}}$ & $305.6^{a}$ & $304.2^{\mathrm{a}}$ & $37.4^{\mathrm{a}}$ & $35.7^{a}$ & $36.1^{\mathrm{a}}$ & $36.8^{a}$ & $36.5^{\mathrm{a}}$ \\
\hline 'Lomik' & $155.3^{c}$ & $152.2^{\mathrm{d}}$ & $148.8^{\mathrm{d}}$ & $143.8^{\mathrm{d}}$ & $150.0^{\mathrm{d}}$ & $19.2^{\mathrm{d}}$ & $18.3^{\mathrm{d}}$ & $17.5^{\mathrm{d}}$ & $17.0^{\mathrm{d}}$ & $18.0^{\mathrm{d}}$ \\
\hline Average & $243.2^{a}$ & $237.2^{b}$ & $236.2^{b}$ & $238.9^{b}$ & 238.9 & $29.5^{a}$ & $28.2^{c}$ & $28.0^{\mathrm{c}}$ & $29.0^{b}$ & 28.7 \\
\hline
\end{tabular}

${ }^{*}$ Explanations as in Table 8. ${ }^{* *}$ Letter indicators at the means (significant groups) define the so-called homogeneous (statistically homogeneous) groups. The presence of the same letter index with the means (at least one) means that there is no statistically significant difference between them. The subsequent letter indices $a, b$, etc., define the groups in ascending order.

It was found that the location of crops, varieties and years had a significant effect on the fresh and dry weight of 100 hop cones. The 'Magnum' variety was characterized by the highest fresh and dry weight of hops in all localities; wherein the variety 'Sybilla' obtained homogeneous results (Table 9).

\subsection{Physical and Mechanical Indicators of the Yield of Cones}

The average cone length of hop was $35.3 \mathrm{~mm}$, the length of spindle of the cone-23.5 mm, and the number of bends in the spindle of the cones-13.5 (Table 10).

Table 10. The cone length of hop, length of spindle cone and number of nodes per cone spindle of hops (2015-2017).

\begin{tabular}{|c|c|c|c|c|c|c|c|c|c|c|c|c|c|c|c|}
\hline \multirow{2}{*}{ Variety } & \multicolumn{5}{|c|}{ Cone Length of Hop (mm) } & \multicolumn{5}{|c|}{ Length of Spindle Cone (mm) } & \multicolumn{5}{|c|}{ Number of Nodes per Cone Spindle of Hops (pcs.) } \\
\hline & A* & B & C & D & $\mathrm{x}$ & A & B & C & $\mathbf{D}$ & $\mathrm{x}$ & A & B & C & D & $\mathrm{X}$ \\
\hline 'Marynka' & $30.6^{\mathrm{c} * *}$ & $28.5^{\mathrm{b}}$ & $28.8^{\mathrm{b}}$ & $29.9^{c}$ & $29.5^{\mathrm{d}}$ & $17.9^{\mathrm{c}}$ & $17.0^{\mathrm{c}}$ & $16.9^{c}$ & $17.1^{\mathrm{b}}$ & $17.2^{\mathrm{e}}$ & $11.2^{\mathrm{b}}$ & $10.2^{c}$ & $10.3^{c}$ & $10.7^{\mathrm{c}}$ & $10.6^{\mathrm{d}}$ \\
\hline 'Iunga' & $33.1^{\mathrm{b}}$ & $31.2^{\mathrm{b}}$ & $31.5^{\mathrm{b}}$ & $31.4^{\mathrm{c}}$ & $31.8^{\mathrm{c}}$ & $25.4^{\mathrm{b}}$ & $22.7^{\mathrm{b}}$ & $23.8^{\mathrm{a}}$ & $23.8^{\mathrm{a}}$ & $23.9^{c}$ & $14.6^{\mathrm{a}}$ & $13.2^{\mathrm{b}}$ & $13.4^{\mathrm{b}}$ & $13.1^{\mathrm{b}}$ & $13.6^{\mathrm{b}}$ \\
\hline 'Magnum' & $41.9^{\mathrm{a}}$ & $40.6^{\mathrm{a}}$ & $39.8^{\mathrm{a}}$ & $40.7^{\mathrm{a}}$ & $40.8^{\mathrm{a}}$ & $29.3^{\mathrm{a}}$ & $28.6^{\mathrm{a}}$ & $28.3^{\mathrm{a}}$ & $28.3^{\mathrm{a}}$ & $28.6^{\mathrm{a}}$ & $16.4^{\mathrm{a}}$ & $16.0^{\mathrm{a}}$ & $15.7^{\mathrm{a}}$ & $15.9^{\mathrm{a}}$ & $16.0^{\mathrm{a}}$ \\
\hline 'Lubelski' & $43.2^{\mathrm{a}}$ & $40.2^{\mathrm{a}}$ & $40.5^{\mathrm{a}}$ & $40.1^{\mathrm{a}}$ & $41.0^{\mathrm{a}}$ & $26.8^{\mathrm{a}}$ & $25.5^{\mathrm{a}}$ & $26.0^{\mathrm{a}}$ & $25.4^{\mathrm{a}}$ & $25.9^{\mathrm{b}}$ & $14.0^{\mathrm{a}}$ & $12.9^{\mathrm{b}}$ & $12.8^{\mathrm{b}}$ & $13.2^{\mathrm{b}}$ & $13.2^{b}$ \\
\hline 'Sybilla' & $37.9^{\text {a }}$ & $37.1^{\mathrm{a}}$ & $36.5^{\mathrm{a}}$ & $37.3^{\mathrm{a}}$ & $37.2^{\mathrm{b}}$ & $26.0^{\mathrm{b}}$ & $24.6^{\mathrm{b}}$ & $24.2^{\mathrm{a}}$ & $24.9^{\mathrm{a}}$ & $24.9^{\mathrm{b}}$ & $16.4^{\mathrm{a}}$ & $15.5^{\mathrm{a}}$ & $15.0^{\mathrm{a}}$ & $15.7^{\mathrm{a}}$ & $15.7^{\mathrm{a}}$ \\
\hline 'Lomik' & $32.7^{\mathrm{b}}$ & $31.5^{\mathrm{b}}$ & $30.9^{b}$ & $32.2^{\mathrm{a}}$ & $31.8^{\mathrm{c}}$ & $21.1^{\mathrm{c}}$ & $20.0^{c}$ & $19.6^{c}$ & $20.9^{b}$ & $20.4^{\mathrm{d}}$ & $12.7^{\mathrm{b}}$ & $11.6^{b c}$ & $11.4^{b c}$ & $12.4^{\mathrm{b}}$ & $12.0^{\mathrm{c}}$ \\
\hline Average & $36.6^{\mathrm{a}}$ & $34.9^{\mathrm{b}}$ & $34.7^{\mathrm{b}}$ & $35.3^{\mathrm{b}}$ & 35.3 & $24.4^{\mathrm{a}}$ & $23.1^{\mathrm{b}}$ & $23.1^{\mathrm{b}}$ & $23.4^{\mathrm{b}}$ & 23.5 & $14.2^{\mathrm{a}}$ & $13.2^{\mathrm{b}}$ & $13.1^{\mathrm{b}}$ & $13.5^{\mathrm{b}}$ & 13.5 \\
\hline
\end{tabular}

${ }^{*}$ Explanations as in Table 8. ${ }^{* *}$ Letter indicators at the means (significant groups) define the so-called homogeneous (statistically homogeneous) groups. The presence of the same letter index with the means (at least one) means that there is no statistically significant difference between them. The subsequent letter indices $a, b$, etc., define the groups in ascending order.

The longest cones were created by the 'Lubelski' variety, while the 'Magnum' variety had the longest of spindle of the cone and the largest number of bends in a cone spindle. The lowest value of all these parameters of cones was characteristic for the 'Marynka' variety. The response of varieties to the meteorological conditions per location was varied. The highest value of all physical features was obtained in the locality A, which should be attributed to the best soil and climatic conditions as well as specific geographic location and terrain (southern exposure, plantation sheltered from winds, especially frosty). The values of the physical characteristics of cones in the remaining localities turned out to be homogeneous (Table 10).

The highest value of all physical parameters of cones was obtained in the first year of the research (2015), when the plants had the greatest vigor and also had the most optimal meteorological conditions for the growth and development of hop plants. The lowest cone 
length, length of spindle the cone; the number of nodes per cone spindle of hops were found in 2017, with a significant shortage of rainfall during the flowering and maturation of the cones. Moreover, the value of the economic characteristics of hops in 2015 and 2016 turned out to be homogeneous to each other (Table 11). The interaction of years and hop varieties in terms of the analyzed traits was found. In the case of the length of the cones, the variations 'Magnum' and 'Sybilla' as well as 'Marynka', 'Iunga' and 'Lomik' showed a homogeneous response to the growing conditions in the years of the research. The 'Magnum' variety was characterized by a homogeneous length of the spindle in the years of research, and the 'Sybilla' and 'Iunga' and 'Lomik' varieties showed a homogeneous value of this feature in the following years. The 'Marynka' variety reacted differently to the conditions in the last year of the research. In the case of the number of nodes per cone spindle of hops, several groups of varieties with a homogeneous reaction to the conditions in the years of the study were distinguished. They were: 'Magnum' and Sybilla'; 'Iunga' and 'Marynka'. On the other hand, the 'Lomik' variety reacted differently in the last year of the research, which was unfavorable in terms of weather conditions (Table 11).

Table 11. The length of the cones and the length of cone spindle as well as the number of nodes per cone spindle of hops depending on the variety and years (Mean for location).

\begin{tabular}{|c|c|c|c|c|c|c|c|c|c|c|c|c|}
\hline \multirow[t]{2}{*}{ Varieties } & \multicolumn{4}{|c|}{ Length of the Cones (mm) } & \multicolumn{4}{|c|}{ Length of Cone Spindle of Hops (mm) } & \multicolumn{4}{|c|}{$\begin{array}{l}\text { Number of Nodes per Cone } \\
\text { Spindle of Hops (Pcs.) }\end{array}$} \\
\hline & 2015 & 2016 & 2017 & $x$ & 2015 & 2016 & 2017 & $x$ & 2015 & 2016 & 2017 & $x$ \\
\hline 'Marynka' & $30.1^{\mathrm{b}^{*}}$ & $29.4^{c}$ & $28.9^{b}$ & $29.5^{\mathrm{d}}$ & $17.5^{\mathrm{d}}$ & $17.1^{\mathrm{d}}$ & $16.8^{\mathrm{c}}$ & $17.1^{\mathrm{c}}$ & $10.9^{c}$ & $10.8^{c}$ & $10.2^{\mathrm{c}}$ & $10.6^{\mathrm{d}}$ \\
\hline 'Iunga' & $32.2^{b}$ & $31.9^{\mathrm{b}}$ & $31.2^{\mathrm{b}}$ & $31.8^{\mathrm{c}}$ & $24.5^{\mathrm{b}}$ & $23.8^{\mathrm{b}}$ & $23.4^{\mathrm{b}}$ & $23.9^{\mathrm{b}}$ & $14.1^{\mathrm{b}}$ & $13.7^{\mathrm{b}}$ & $13.1^{\mathrm{b}}$ & $13.6^{\mathrm{b}}$ \\
\hline 'Magnum' & $41.6^{\mathrm{a}}$ & $41.0^{\mathrm{a}}$ & $39.8^{\mathrm{a}}$ & $40.8^{\mathrm{a}}$ & $29.1^{a}$ & $28.5^{\mathrm{a}}$ & $28.1^{\mathrm{a}}$ & $28.6^{\mathrm{a}}$ & $16.8^{\mathrm{a}}$ & $16.2^{\mathrm{a}}$ & $15.1^{\mathrm{a}}$ & $16.0^{\mathrm{a}}$ \\
\hline 'Sybilla' & $38.3^{\mathrm{a}}$ & $37.0^{\mathrm{a}}$ & $36.2^{\mathrm{a}}$ & $37.2^{\mathrm{b}}$ & $25.6^{b}$ & $25.0^{\mathrm{b}}$ & $24.2^{b}$ & $24.9^{b}$ & $16.3^{\mathrm{a}}$ & $16.1^{\mathrm{a}}$ & $14.9^{\mathrm{a}}$ & $15.7^{\mathrm{a}}$ \\
\hline 'Lomik' & $32.5^{\mathrm{b}}$ & $31.9^{\mathrm{b}}$ & $31.1^{\mathrm{b}}$ & $31.8^{c}$ & $21.2^{\mathrm{C}}$ & $20.4^{\mathrm{c}}$ & $19.7^{c}$ & $20.4^{b c}$ & $12.7^{\mathrm{b}}$ & $12.3^{\mathrm{b}}$ & $11.1^{\mathrm{c}}$ & $12.0^{\mathrm{c}}$ \\
\hline Average & $34.9^{a}$ & $34.2^{\mathrm{a}}$ & $33.4^{\mathrm{b}}$ & 34.2 & $23.6^{a}$ & $23.0^{\mathrm{b}}$ & $22.4^{\mathrm{c}}$ & 23.5 & $14.2^{\mathrm{a}}$ & $13.8^{\mathrm{a}}$ & $12.9^{b}$ & 13.5 \\
\hline
\end{tabular}

${ }^{*}$ Letter indicators at the means (significant groups) define the so-called homogeneous (statistically homogeneous) groups. The presence of the same letter index with the means (at least one) means that there is no statistically significant difference between them. The subsequent letter indices $a, b$, etc., define the groups in ascending order

The indicator of the specific weight of cones in the authors' own research oscillated between 0.88 and 1.52 (Figure 6). The 'Marynka' variety obtained the highest specific weight index of cones; the 'Sybilla' variety was homogeneous in terms of the value of this feature. The 'Magnum', 'Sybilla', 'Lubelski' and 'Lomik' varieties turned out to be homogeneous in terms of this feature, and the 'Iunga' variety had the lowest value of this indicator.

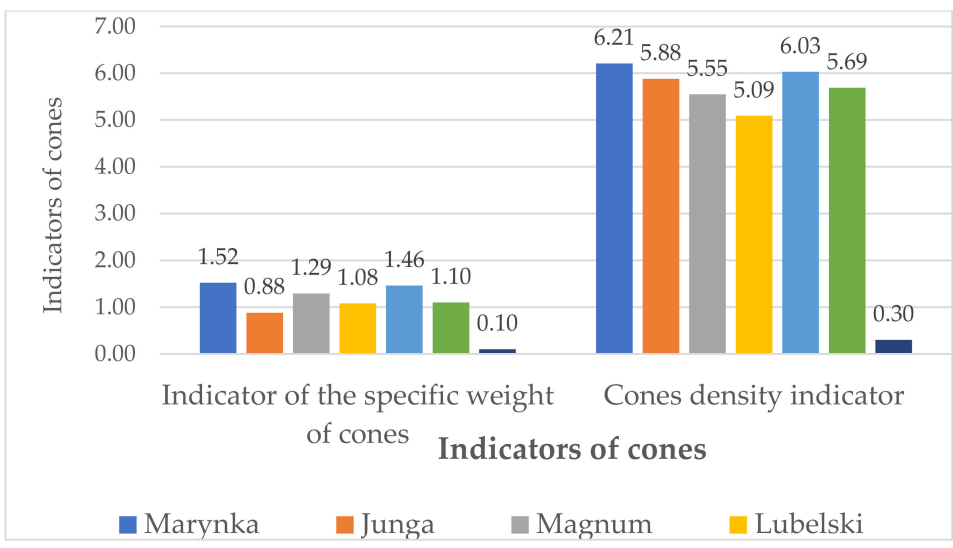

Figure 6. Indices of physicochemical evaluation of hop cones (average for location and years). 
On average, the cone compactness index, in the conducted research, ranged from 5.09 to 6.21 (Figure 6). It is assumed that for the most noble cones, the cones compactness index exceeds the value of 6.5, for medium-quality cones this index ranges from 5.5 to 6.5 , and for cones of lower quality, the so-called in 'ordinary' cones, this indicator does not exceed $5.5[12,14]$. The value of this index was mainly determined by the varietal characteristics of the hops. The 'Marynka' cultivar was also characterized by the highest cone density index, the 'Sybilla' cultivar was homogeneous in this respect. Homogeneous groups formed the varieties of 'Iunga' and 'Lomik' and 'Magnum' and Lomik'. The oldest variety of 'Lubelski' had the lowest value of this index (Figure 6). The location of hops and the years of research did not have a significant impact on the value of both of these cone indicators.

\subsection{Chemical Composition of Hop Cones}

The chemical composition of cones, especially hop resins and oils, is presented in Tables 11-15. The content of both alpha- and beta-acids significantly depended on the variety, location, and meteorological conditions in the years of the study (Table 12). The heat and droughts in the period of cones' ripening were not conducive to the accumulation of al-fa-acids, except for the 'Marynka' variety.

Table 12. Share of alpha acids and beta acids in hop cones depending on the variety and locality (Mean 2015-2017).

\begin{tabular}{|c|c|c|c|c|c|c|c|c|c|c|}
\hline \multirow{2}{*}{ Varieties } & \multicolumn{5}{|c|}{ Alfa-acids (\%) } & \multicolumn{5}{|c|}{ Beta-acids (\%) } \\
\hline & $\mathbf{A}^{*}$ & B & C & D & $X$ & A & B & C & $\mathrm{D}$ & $X$ \\
\hline 'Marynka' & $7.5^{b * *}$ & $7.9^{b}$ & $8.7^{b}$ & $9.6^{b}$ & $8.4^{c}$ & $4.3^{b}$ & $4.6^{b}$ & $4.8^{b}$ & $4.6^{b}$ & $4.7^{\mathrm{b}}$ \\
\hline 'Iunga' & $11.8^{\mathrm{a}}$ & $11.0^{\mathrm{a}}$ & $10.6^{a}$ & $11.7^{\mathrm{a}}$ & $11.3^{b}$ & $6.4^{\mathrm{a}}$ & $6.2^{\mathrm{a}}$ & $6.0^{\mathrm{a}}$ & $6.2^{\mathrm{a}}$ & $6.4^{\mathrm{a}}$ \\
\hline 'Magnum' & $12.5^{\mathrm{a}}$ & $11.5^{\mathrm{a}}$ & $11.5^{\mathrm{a}}$ & $12.7^{\mathrm{a}}$ & $12.1^{\mathrm{a}}$ & $5.9^{\mathrm{a}}$ & $6.5^{\mathrm{a}}$ & $7.0^{\mathrm{a}}$ & $6.5^{\mathrm{a}}$ & $6.6^{\mathrm{a}}$ \\
\hline 'Lubelski' & $4.3^{c}$ & $4.2^{\mathrm{d}}$ & $4.0^{\mathrm{d}}$ & $4.4^{\mathrm{d}}$ & $4.2^{\mathrm{e}}$ & $4.6^{\mathrm{b}}$ & $4.5^{b}$ & $4.1^{b}$ & $4.4^{\mathrm{b}}$ & $4.5^{b}$ \\
\hline 'Sybilla' & $6.1^{b}$ & $6.0^{\mathrm{c}}$ & $6.2^{c}$ & $6.8^{c}$ & $6.3^{\mathrm{d}}$ & $3.5^{b c}$ & $3.5^{b c}$ & $3.8^{b}$ & $3.6^{b}$ & $3.7^{c}$ \\
\hline 'Lomik' & $4.3^{c}$ & $4.0^{\mathrm{d}}$ & $4.6^{\mathrm{d}}$ & $5.1^{\mathrm{d}}$ & $4.5^{\mathrm{e}}$ & $4.2^{b}$ & $4.0^{b}$ & $3.4^{\mathrm{c}}$ & $3.9^{b}$ & $4.0^{\circ}$ \\
\hline Average & $7.8^{b}$ & $7.4^{\mathrm{bc}}$ & $7.6^{b}$ & $8.4^{\mathrm{a}}$ & 7.8 & $4.8^{b}$ & $4.9^{b}$ & $4.9^{b}$ & $5.4^{\mathrm{a}}$ & 5.0 \\
\hline
\end{tabular}

* Designations of localities as in Table 1. ** Letter indicators at the means (significant groups) define the so-called homogeneous (statistically homogeneous) groups. The presence of the same letter index with the means (at least one) means that there is no statistically significant difference between them. The subsequent letter indices $a, b$, etc., define the groups in ascending order.

Table 13. Share of alpha-acids and beta-acids in hop cones depending on the variety and years (Mean for locations).

\begin{tabular}{ccccccccc}
\hline \multirow{2}{*}{ Varieties } & \multicolumn{4}{c}{ Alfa-Acids (\%) } & \multicolumn{5}{c}{ Beta-Acids (\%) } \\
\cline { 2 - 9 } & $\mathbf{2 0 1 5}$ & $\mathbf{2 0 1 6}$ & $\mathbf{2 0 1 7}$ & $\mathbf{X}$ & $\mathbf{2 0 1 5}$ & $\mathbf{2 0 1 6}$ & $\mathbf{2 0 1 7}$ & $\mathbf{X}$ \\
\hline 'Marynka' & $8.7^{\mathrm{b} *}$ & $8.5^{\mathrm{b}}$ & $8.1^{\mathrm{b}}$ & $8.4^{\mathrm{b}}$ & $4.9^{\mathrm{b}}$ & $4.8^{\mathrm{b}}$ & $4.5^{\mathrm{b}}$ & $4.7^{\mathrm{b}}$ \\
'Iunga' & $11.6^{\mathrm{a}}$ & $11.3^{\mathrm{a}}$ & $11.0^{\mathrm{a}}$ & $11.3^{\mathrm{a}}$ & $6.6^{\mathrm{a}}$ & $6.5^{\mathrm{a}}$ & $6.1^{\mathrm{a}}$ & $6.4^{\mathrm{a}}$ \\
'Magnum' & $12.6^{\mathrm{a}}$ & $12.0^{\mathrm{a}}$ & $11.6^{\mathrm{a}}$ & $12.1^{\mathrm{a}}$ & $6.9^{\mathrm{a}}$ & $6.9^{\mathrm{a}}$ & $6.0^{\mathrm{a}}$ & $6.6^{\mathrm{a}}$ \\
'Lubelski' & $4.5^{\mathrm{c}}$ & $4.3^{\mathrm{d}}$ & $3.9^{\mathrm{d}}$ & $4.2^{\mathrm{d}}$ & $5.0^{\mathrm{b}}$ & $4.5^{\mathrm{b}}$ & $4.0^{\mathrm{b}}$ & $4.5^{\mathrm{b}}$ \\
'Sybilla' & $6.6^{\mathrm{b}}$ & $6.4^{\mathrm{c}}$ & $5.9^{\mathrm{c}}$ & $6.3^{\mathrm{c}}$ & $4.0^{\mathrm{b}}$ & $3.8^{\mathrm{bc}}$ & $4.0^{\mathrm{b}}$ & $3.7^{\mathrm{c}}$ \\
'Lomik' & $5.0^{\mathrm{c}}$ & $4.6^{\mathrm{d}}$ & $4.0^{\mathrm{d}}$ & $4.5^{\mathrm{d}}$ & $4.4^{\mathrm{b}}$ & $4.1^{\mathrm{b}}$ & $3.2^{\mathrm{c}}$ & $4.0^{\mathrm{c}}$ \\
\hline Average & $8.2^{\mathrm{a}}$ & $7.8^{\mathrm{b}}$ & $7.4^{\mathrm{c}}$ & $7.8^{\mathrm{b}}$ & $5.3^{\mathrm{a}}$ & $5.1^{\mathrm{a}}$ & $3.6^{\mathrm{b}}$ & $5.0^{\mathrm{b}}$
\end{tabular}

* Letter indicators at the means (significant groups) define the so-called homogeneous (statistically homogeneous) groups. The presence of the same letter index with the means (at least one) means that there is no statistically significant difference between them. The subsequent letter indices $a, b$, etc., define the groups in ascending order. 
Table 14. The content of essential oils in total and the share of myrcene, humulene, farnesene and caryophyllene in hop cones depending on the location and years (Mean for varieties).

\begin{tabular}{|c|c|c|c|c|c|c|c|c|}
\hline \multirow{2}{*}{ Specification } & \multicolumn{4}{|c|}{ Location * } & \multicolumn{3}{|c|}{ Years } & \multirow{2}{*}{ Average } \\
\hline & A & B & $\mathrm{C}$ & D & 2015 & 2016 & 2017 & \\
\hline Total oils (mL $\left.100 \mathrm{~g}^{-1}\right)$ & $1.9^{a * *}$ & $1.7^{\mathrm{a}}$ & $1.6^{\mathrm{a}}$ & $1.8^{\mathrm{a}}$ & $1.9^{\mathrm{a}}$ & $1.8^{\mathrm{a}}$ & $1.5^{b}$ & 1.7 \\
\hline Myrcene (\%) & $39.3^{b}$ & $39.5^{b}$ & $37.7^{\mathrm{b}}$ & $45.1^{\mathrm{a}}$ & $41.4^{\mathrm{a}}$ & $40.7^{\mathrm{a}}$ & $39.0^{b}$ & 40.4 \\
\hline Humulene (\%) & $22.3^{b}$ & $20.7^{b c}$ & $21.4^{b c}$ & $26.8^{a}$ & $23.4^{\mathrm{a}}$ & $23.1^{\mathrm{a}}$ & $21.9^{b}$ & 22.8 \\
\hline Farnesene $(\%)$ & $7.8^{\mathrm{a}}$ & $7.9^{b}$ & $7.8^{b}$ & $7.8^{\mathrm{a}}$ & $8.0^{\mathrm{a}}$ & $7.9^{\mathrm{a}}$ & $7.6^{\mathrm{b}}$ & 6.7 \\
\hline Caryophyllene (\%) & $6.5^{b}$ & $6.0^{c}$ & $6.2^{c}$ & $7.8^{\mathrm{a}}$ & $7.1^{\mathrm{a}}$ & $6.8^{\mathrm{a}}$ & $6.0^{\mathrm{b}}$ & 6.6 \\
\hline
\end{tabular}

${ }^{*}$ Designations of localities as in Table $1 .{ }^{* *}$ Letter indicators at the means (significant groups) define the so-called homogeneous (statistically homogeneous) groups. The presence of the same letter index with the means (at least one) means that there is no statistically significant difference between them. The subsequent letter indices $a, b$, etc., define the groups in ascending order.

The 'Magnum' variety had the highest share of both alpha- and beta-acids, 'Iunga' turned out to be homogeneous in this respect, and the 'Marynka' variety a significantly lower share of alpha-acids stood out. The 'Sybilla' variety was in the next group in terms of the content of these compounds, and the 'Lubelski' and 'Lomik' varieties were in the group with the lowest alpha-acid content in cones. In terms of the content of beta-acids, there are three homogeneous groups of hop varieties. The cultivars with the highest proportion of beta acids are: 'Magnum' and 'Iunga', in the next group there are 'Marynka' and 'Lubelski' and in the last one-'Sybilla' and 'Lomik' (Table 12).

The highest share of both alpha- and beta-acids in cones was found in 2015, a significantly lower share of alpha-acids was found in cones in 2016 and the lowest in 2017, with the least favorable weather conditions for the formation of lupulin in the cones (Table 13). The Magnum and 'Iunga' varieties produced the highest amount of alpha- and beta-acids in all years. The 'Lubelski' variety was characterized by the lowest share of alpha acids in all years of research; the variation of 'Lomik' turned out to be homogeneous in terms of this feature in the years 2016-2017. The 'Sybilla' variety had the lowest share of beta-acids in essential oils; however, in 2017 the 'Lomik' variety turned out to be homogeneous in terms of the value of this feature (Table 13).

Half of the varieties studied ('Lubelski', 'Lomik' and 'Sybilla') can be classified as aromatic varieties, while the other half ('Marynka', 'Iunga' and 'Magnum') as bitter varieties (Table 13). In bitter varieties, the ratio of alpha-acids to beta-acids was homogeneous and ranged from 1.77-1.83, while in aromatic varieties this ratio was variable and ranged from 0.93 in the case of the oldest aromatic variety in Poland, 'Lubelski', to 1.70 in the case of the variety later breeding 'Lomik' (Figure 7).

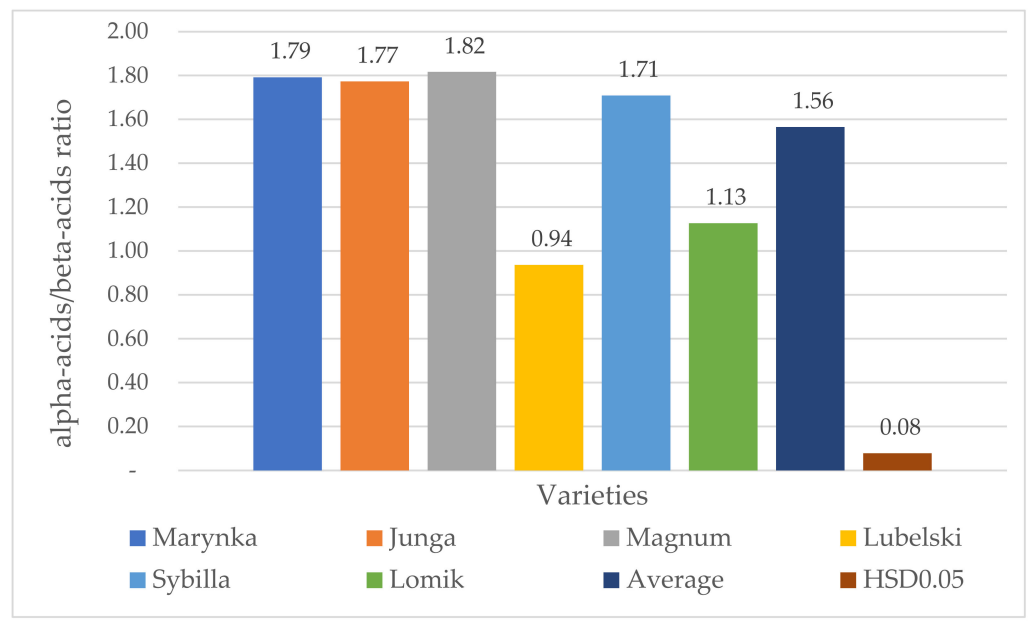

Figure 7. The ratio of alpha-acids to beta-acids in hop cones depending on the variety. 
Table 15. The influence of location and varieties on the content of total oils and the share of myrcene, humulene, farnesene and caryophyllene (2015-2017).

\begin{tabular}{|c|c|c|c|c|c|c|c|c|c|c|c|c|c|c|c|c|c|c|c|c|}
\hline \multirow{3}{*}{ Varieties } & \multicolumn{4}{|c|}{$\begin{array}{l}\text { Total oil content } \\
\left(\mathrm{mL} 100 \mathrm{~g}^{-1}\right)\end{array}$} & \multicolumn{4}{|c|}{ Myrcene (\%) } & \multicolumn{4}{|c|}{ Humulene (\%) } & \multicolumn{4}{|c|}{ Farnesene (\%) } & \multicolumn{4}{|c|}{ Caryophyllene (\%) } \\
\hline & \multicolumn{20}{|c|}{ Location * } \\
\hline & $\mathbf{A}$ & B & $\mathrm{C}$ & $\mathbf{D}$ & $\mathbf{A}$ & B & $\mathrm{C}$ & D & A & B & C & D & A & B & $\mathrm{C}$ & D & A & B & $\mathrm{C}$ & $\mathbf{D}$ \\
\hline 'Marynka' & $2.2^{\mathrm{a}^{* *}}$ & $2.3^{\mathrm{a}}$ & $2.4^{\mathrm{a}}$ & $2.6^{a}$ & $32.0^{\mathrm{a}}$ & $35.0^{\mathrm{a}}$ & $33.0^{\mathrm{a}}$ & $33.0^{\mathrm{a}}$ & $20.0^{\mathrm{b}}$ & $19.0^{\mathrm{b}}$ & $21.0^{b}$ & $25.0^{\mathrm{a}}$ & $15.0^{\mathrm{a}}$ & $16.0^{\mathrm{a}}$ & $15.0^{\mathrm{a}}$ & $15.0^{\mathrm{a}}$ & $5.0^{\mathrm{b}}$ & $5.0^{\mathrm{b}}$ & $5.0^{\mathrm{b}}$ & $6.3^{\mathrm{a}}$ \\
\hline 'Iunga' & $2.2^{\mathrm{a}}$ & $2.0^{\mathrm{a}}$ & $2.0^{\mathrm{a}}$ & $2.2^{\mathrm{a}}$ & $50.0^{\mathrm{a}}$ & $52.0^{\mathrm{a}}$ & $49.0^{\mathrm{a}}$ & $52.0^{\mathrm{a}}$ & $20.0^{b}$ & $19.0^{\mathrm{b}}$ & $21.0^{\mathrm{b}}$ & $25.0^{\mathrm{a}}$ & $0.9^{\mathrm{a}}$ & $0.8^{\mathrm{a}}$ & $0.8^{\mathrm{a}}$ & $0.7^{\mathrm{a}}$ & $7.0^{\mathrm{b}}$ & $7.0^{\mathrm{b}}$ & $7.0^{\mathrm{b}}$ & $8.8^{\mathrm{a}}$ \\
\hline Magnum' & $2.1^{\mathrm{a}}$ & $2.0^{\mathrm{a}}$ & $2.0^{\mathrm{a}}$ & $2.2^{\mathrm{a}}$ & $32.0^{\mathrm{b}}$ & $32.0^{\mathrm{b}}$ & $30.0^{\mathrm{b}}$ & $38.0^{\mathrm{a}}$ & $32.0^{\mathrm{b}}$ & $30.0^{c}$ & $34.0^{\mathrm{b}}$ & $40.0^{\mathrm{a}}$ & $1.0^{\mathrm{a}}$ & $0.7^{\mathrm{a}}$ & $0.8^{\mathrm{a}}$ & $0.9^{\mathrm{a}}$ & $9.0^{\mathrm{b}}$ & $8.0^{c}$ & $9.0^{\mathrm{b}}$ & $10.8^{\mathrm{a}}$ \\
\hline Lubelski' & $2.1^{\mathrm{a}}$ & $1.0^{\mathrm{b}}$ & $1.0^{\mathrm{b}}$ & $1.1^{\mathrm{b}}$ & $42.0^{\mathrm{b}}$ & $40.0^{\mathrm{b}}$ & $41.0^{\mathrm{b}}$ & $51.3^{\mathrm{a}}$ & $22.0^{\mathrm{a}}$ & $19.0^{\mathrm{b}}$ & $16.0^{\mathrm{b}}$ & $23.8^{\mathrm{a}}$ & $14.4^{\mathrm{a}}$ & $14.3^{\mathrm{a}}$ & $14.6^{\mathrm{a}}$ & $14.5^{\mathrm{a}}$ & $5.0^{\mathrm{a}}$ & $4.0^{\mathrm{b}}$ & $4.0^{\mathrm{b}}$ & $5.4^{\mathrm{a}}$ \\
\hline 'Sybilla' & $1.8^{\mathrm{a}}$ & $1.8^{\mathrm{a}}$ & $1.6^{\mathrm{a}}$ & $1.8^{\mathrm{a}}$ & $43.0^{\mathrm{b}}$ & $44.0^{\mathrm{b}}$ & $40.0^{\mathrm{b}}$ & $52.9^{a}$ & $19.0^{\mathrm{a}}$ & $18.0^{\mathrm{b}}$ & $18.3^{\mathrm{b}}$ & $22.9^{\mathrm{a}}$ & $9.6^{a}$ & $8.9^{\mathrm{a}}$ & $9.2^{\mathrm{a}}$ & $9.0^{\mathrm{a}}$ & $6.0^{b}$ & $6.0^{\mathrm{b}}$ & $6.1^{\mathrm{b}}$ & $7.4^{\mathrm{a}}$ \\
\hline Average & $1.9^{\mathrm{a}}$ & $1.7^{\mathrm{a}}$ & $1.6^{\mathrm{a}}$ & $1.8^{\mathrm{a}}$ & $39.3^{b}$ & $39.5^{b}$ & $37.7 \mathrm{bc}$ & $45.1^{\mathrm{a}}$ & $22.3^{b}$ & $20.7^{c}$ & $21.4^{\mathrm{c}}$ & $26.8^{\mathrm{a}}$ & $7.8^{\mathrm{a}}$ & $7.9^{a}$ & $7.8^{\mathrm{a}}$ & $7.8^{\mathrm{a}}$ & $6.5^{b}$ & $6.0^{\mathrm{b}}$ & $6.2^{\mathrm{b}}$ & $7.8^{\mathrm{a}}$ \\
\hline
\end{tabular}

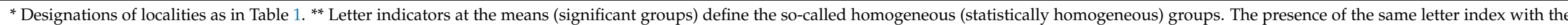
means (at least one) means that there is no statistically significant difference between them. The subsequent letter indices $a, b$, etc., define the groups in ascending order. 
The content of essential oils was at a similar level, from 1.6 to $1.8 \mathrm{~mL} 100 \mathrm{~g}^{-1}$ and did not differ significantly between localities, but it differed over the years of the study (Table 14). Most of them were produced by hop cones in dry 2015, and the least in 2017, characterized by drought in August, which is the period of formation and filling of the cones. The content of essential oils in 2015 and 2016 was homogeneous in terms of the value of this feature. Among the components of essential oils, myrcene had the highest share $(40.4 \%$ on average). Its content was significantly influenced by both the location and the meteorological conditions in the years of the study. The highest share of this component of oils was found in cones from D location, and the lowest in B location. In dry, 2015, hop plants produced the most of this essential oil component, and the least-in 2017, when August was dry. The share of myrcene in oils turned out to be homogeneous in 2015 and 2016. The content of a particularly desirable component of essential oils-humulene, was on average $22.8 \%$, both the localities and the years of research influenced the value of this feature. Its highest share in oils was found in location D, and the lowest in B, while the share of humulene was homogeneous in location A and C. The average share of farnesene was $7.8 \%$ in essential oils and depended on the locality and conditions in the years of the research. In terms of farnesene content, the 'Marynka' and 'Lubelski' varieties stood out. The highest content of these compounds was found in location $\mathrm{D}$, the lowest in location $\mathrm{B}$, whereas in the A and D, as well as B and C, locations the participation of myrcene was homogeneous. The highest share of farnesene in cones was found in 2015, and the lowest in 2017; in 2015 and 2016, the value of this feature turned out to be homogeneous. The share of caryophyllene in essential oils was $6.6 \%$ on average. In location D, with exceptionally favorable exposure and soil conditions, its highest share was recorded, and the lowest in location B. The share of caryophyllene in locations A, B and C turned out to be homogeneous. The highest share of this component in essential oils was found in 2015, and the lowest in 2017. The participation of this component in oils in 2015 and 2016 was homogeneous in terms of the value of this feature (Tables 14-16).

Table 16. Influence of varieties and years on the content of oils and the share of myrcene, humulene, farnesene and caryophyllene (mean of location).

\begin{tabular}{|c|c|c|c|c|c|c|c|c|c|c|c|c|c|c|c|}
\hline \multirow{3}{*}{ Varieties } & \multicolumn{3}{|c|}{$\begin{array}{l}\text { Total Oil Content } \\
\quad\left(\mathrm{mL} 100 \mathrm{~g}^{-1}\right)\end{array}$} & \multicolumn{3}{|c|}{ Myrcene (\%) } & \multicolumn{3}{|c|}{ Humulene (\%) } & \multicolumn{3}{|c|}{ Farnesene (\%) } & \multicolumn{3}{|c|}{ Caryophyllene (\%) } \\
\hline & \multicolumn{15}{|c|}{ Years } \\
\hline & 2015 & 2016 & 2017 & 2015 & 2016 & 2017 & 2015 & 2016 & 2017 & 2015 & 2016 & 2017 & 2015 & 2016 & 2017 \\
\hline 'Marynka' & $2.5^{a *}$ & $2.5^{\mathrm{a}}$ & $2.2^{b}$ & $33.5^{\mathrm{a}}$ & $33.7^{\mathrm{a}}$ & $32.3^{\mathrm{a}}$ & $21.7^{a}$ & $21.5^{\mathrm{a}}$ & $20.6^{a}$ & $15.6^{\mathrm{a}}$ & $15.7^{\mathrm{a}}$ & $14.6^{b}$ & $5.8^{\mathrm{a}}$ & $5.3^{\mathrm{a}}$ & $4.9^{\mathrm{a}}$ \\
\hline 'Junga' & $2.3^{\mathrm{a}}$ & $2.3^{\mathrm{a}}$ & $1.8^{\mathrm{b}}$ & $52.1^{\mathrm{a}}$ & $50.9^{a}$ & $49.0^{\mathrm{a}}$ & $21.7^{\mathrm{a}}$ & $21.5^{\mathrm{a}}$ & $20.6^{\mathrm{a}}$ & $0.9^{\mathrm{a}}$ & $0.8^{\mathrm{a}}$ & $0.6^{\mathrm{a}}$ & $7.8^{\mathrm{a}}$ & $7.8^{\mathrm{a}}$ & $6.8^{\mathrm{b}}$ \\
\hline Lubelski' & $2.4^{\mathrm{a}}$ & $2.2^{\mathrm{a}}$ & $1.8^{\mathrm{b}}$ & $34.4^{\mathrm{a}}$ & $33.2^{\mathrm{a}}$ & $31.3^{\mathrm{a}}$ & $34.3^{\mathrm{a}}$ & $34.6^{\mathrm{a}}$ & $33.2^{\mathrm{a}}$ & $0.9^{\mathrm{a}}$ & $0.8^{\mathrm{a}}$ & $0.7^{\mathrm{a}}$ & $10.0^{\mathrm{a}}$ & $9.4^{\mathrm{a}}$ & $8.3^{b}$ \\
\hline 'Magnum' & $1.2^{\mathrm{a}}$ & $1.1^{\mathrm{a}}$ & $0.9^{b}$ & $44.5^{\mathrm{a}}$ & $43.9^{a}$ & $42.3^{a}$ & $21.3^{a}$ & $20.8^{a}$ & $18.6^{b}$ & $14.7^{\mathrm{a}}$ & $14.4^{\mathrm{a}}$ & $14.0^{\mathrm{a}}$ & $4.9^{\mathrm{a}}$ & $4.8^{\mathrm{a}}$ & $4.2^{\mathrm{a}}$ \\
\hline 'Sybilla' & $2.0^{\mathrm{a}}$ & $1.8^{\mathrm{a}}$ & $1.5^{\mathrm{b}}$ & $46.5^{\mathrm{a}}$ & $45.3^{\mathrm{a}}$ & $43.1^{\mathrm{a}}$ & $20.3^{a}$ & $19.7^{\mathrm{a}}$ & $18.6^{\mathrm{b}}$ & $9.3^{\mathrm{a}}$ & $8.9^{a}$ & $9.4^{\mathrm{a}}$ & $6.9^{\mathrm{a}}$ & $6.5^{\mathrm{a}}$ & $6.0^{\mathrm{a}}$ \\
\hline 'Lomik' & $0.9^{\mathrm{a}}$ & $0.8^{\mathrm{a}}$ & $0.7^{\mathrm{a}}$ & $37.5^{\mathrm{a}}$ & $37.0^{\mathrm{a}}$ & $36.1^{\mathrm{a}}$ & $21.3^{\mathrm{a}}$ & $20.5^{\mathrm{a}}$ & $19.9^{b}$ & $6.4^{\mathrm{a}}$ & $6.5^{\mathrm{a}}$ & $6.4^{\mathrm{a}}$ & $7.0^{\mathrm{a}}$ & $7.0^{\mathrm{a}}$ & $6.2^{\mathrm{a}}$ \\
\hline Average & $1.9^{\mathrm{a}}$ & $1.8^{\mathrm{a}}$ & $1.5^{\mathrm{b}}$ & $41.4^{\mathrm{a}}$ & $40.7^{\mathrm{a}}$ & $39.0^{b}$ & $23.4^{\mathrm{a}}$ & $23.1^{\mathrm{a}}$ & $21.9^{b}$ & $8.0^{\mathrm{a}}$ & $7.9^{a}$ & $7.6^{\mathrm{b}}$ & $7.1^{\mathrm{a}}$ & $6.8^{\mathrm{a}}$ & $6.0^{\mathrm{b}}$ \\
\hline
\end{tabular}

* Letter indicators at the means (significant groups) define the so-called homogeneous (statistically homogeneous) groups. The presence of the same letter index with the means (at least one) means that there is no statistically significant difference between them. The subsequent letter indices $a, b$, etc., define the groups in ascending order.

The reaction of hop varieties to the cultivation location was manifested only in the case of the total content of oils in the 'Lubelski' variety, which reacted with a significantly higher content of oils in location A, compared to the others locations. The share of myrcene in oils depended, in the case of the varieties' Iunga, 'Magnum', 'Sybilla' and 'Lomik', on the geographical location. Significantly higher share of these compounds was found in the cones from the location D than in other places. In the case of humulene and caryophyllene, in all the varieties studied, a higher proportion of these substances was observed in location D, which was distinguished by the most favorable exhibition of hop plantations and the specific, favorable microclimate of this place, compared to other localities (Table 15).

The content of hop essential oils and the share of its most important components turned out to be dependent on the interaction of varieties and meteorological conditions in the research years (Table 16). Only the 'Lomik' cultivar did not react with the content of 
essential oils to meteorological conditions in the years of research, the remaining cultivars showed a negative reaction to drought in the period of formation and maturation of cones in August. The share of humulene in the 'Sybilla' and 'Lomik' varieties turned out to be significantly lower in 2017, with a drought period during cones' ripening. The 'Marynka' variety reacted in a similar way, i.e., with a lower participation in farnesene and 'Iunga' and 'Lubelski' olefines, with a significantly lower share of caryophyllene in 2017, compared to the remaining years of the research (Table 16).

\subsection{The Ratio of Myrcene to Humulene}

An important parameter of the quality assessment of hop cones is the ratio of the myrcene to the humulene. Among the examined cultivars, the cultivars 'Iunga' and 'Sybilla' $(2.38 ; 2.31$, respectively) were characterized by the highest ratio (Figure 8$)$. However, due to the unfavorable effect of myrcene, with an unpleasant taste and smell in the bouquet of hop aromas, the 'Magnum' variety was characterized by the lowest ratio of myrcene to humulene, while the bitter variety 'Sybilla' had a relatively a higher proportion of myrcene and a higher ratio of myrcene to humulene (Figure 8).

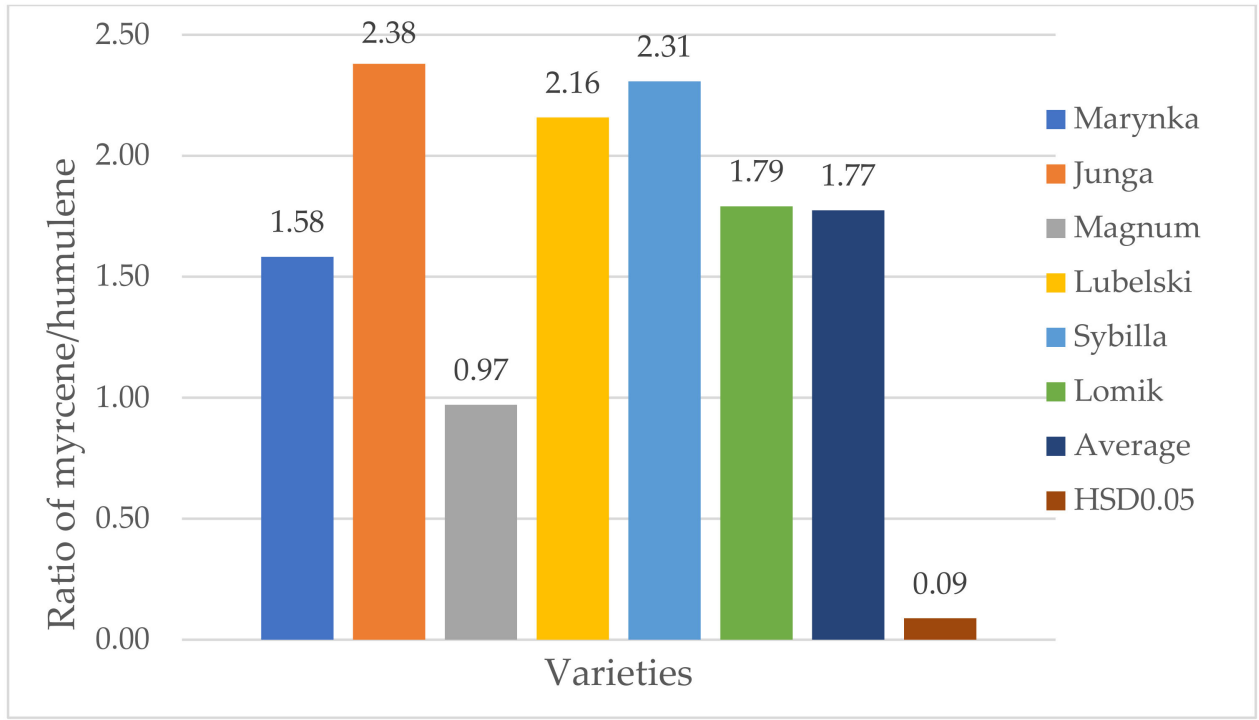

Figure 8. Myrcene to humulene ratio (Mean for locations and years).

The highest ratio of the myrcene to the humulene was obtained in localities $\mathrm{C}$ and $\mathrm{A}$, and the lowest-in location B. This indicator, however, did not differ significantly in the years of the study (Figure 9). 


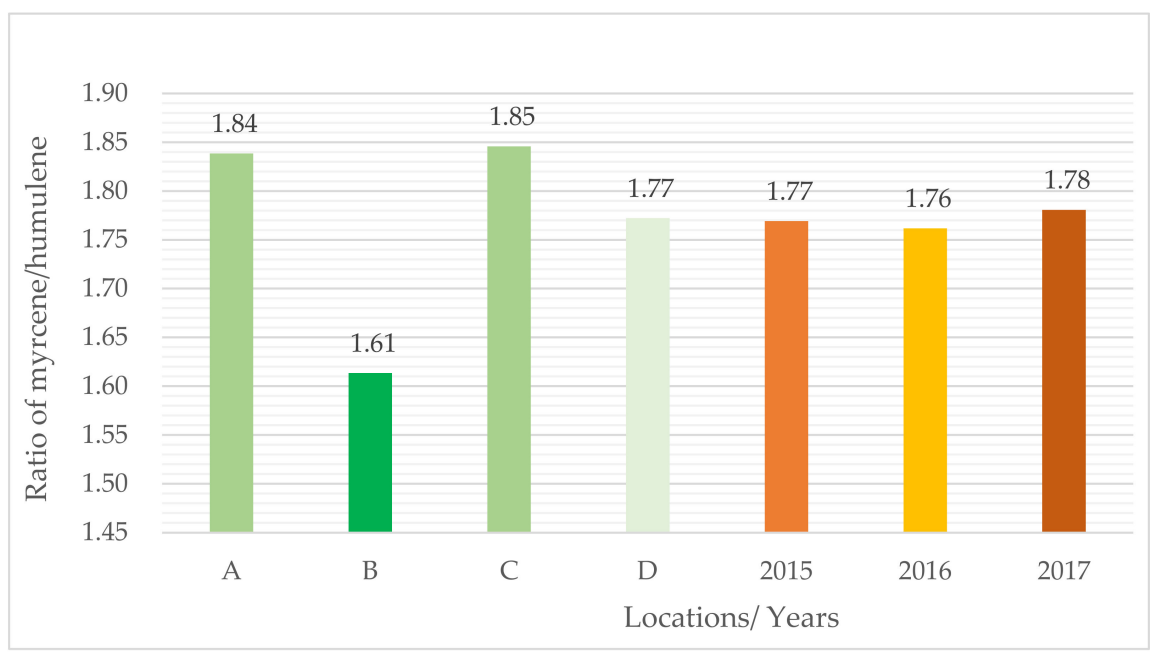

Figure 9. Myrcene to humulene ratio in hop cones depending on localities and years (Mean for varieties).

\subsection{Variabilities of Yield and Physical and Chemical Composition Characteristics of Hop Cones}

In the conducted research, the site conditions were the main factor determining the variability of the yield of cones, their structure and chemical composition (20.4\%) (Table 17).

According to the results, another important source of variation was the interaction of varieties and years (19.7\%), the interaction of years, locations, and varieties $(15.7 \%)$, years $x$ location $(15.1 \%)$, varieties $(13.3 \%)$, varieties $x$ locations $(10.3 \%)$, and locations $(5.0 \%)$. The conditions in the research years were on the first, and the cultivars and localizations were the fifth and seventh sources of variation due to the importance of the factor. Varietal traits had an average share of $13.3 \%$ in shaping the yield value; for the physical and chemical characteristics of cones; this value ranged from 10.9 to $29.5 \%$. The feature least dependent on the variety was the content of beta-acids, and the most, the number of nodes per each spindle of hop. The double interaction of varieties $x$ years was on the second in the ranking of the percentage share of variation sources in phenotypic variability (on average 19.7\%) and ranged from $4.4 \%$ for the yield of cones to $34.2 \%$ for the content of essential oils. The fourth place was taken by the interaction of the variety $\times$ localization $(15.1 \%)$ with a wide range of variability from $1.1 \%$ (the number of nodes per cone spindle of hop) to $44.7 \%$, in the case of myrcene share. The fifth place in the ranking of sources of variability was occupied by the varietal traits of hops (13.3\%), with fluctuations from 3.5\% (share of beta-acids) to $29.5 \%$ (the numbers of nodes per cone spindle of hop). Ultimately, on the seventh largest place to the phenotypic variability was the study location (5.0\%). The geographic origin of the varieties was in this case less important for the physical and chemical properties of the hop cones. The share of this source in phenotypic variability ranged from $0.1 \%$ (share of beta-acids) to $15.2 \%$ in the case of a fresh weight of 100 cones (Table 17). 
Table 17. Effect of cultivars, locality, and years on the chemical composition of $H$. lupulus and their percent contribution to the total variance.

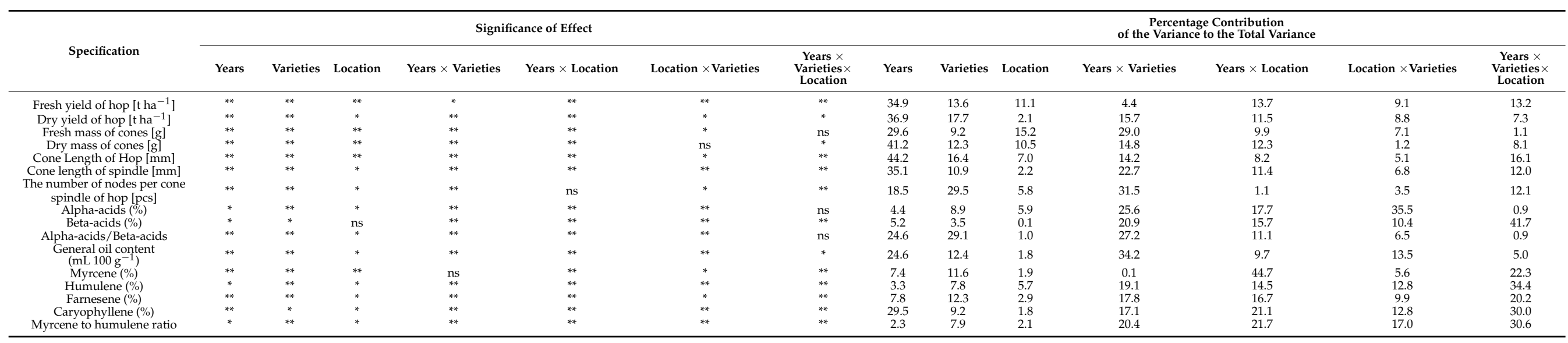

* Significant at $p=0.05 ; * *$ significant at $p=0.01, \mathrm{~ns}-$ not significant at $p=0.05$ 


\section{Discussion}

McKinnon et al. [43] think that the impact of weather fluctuations on the production of hop alpha-acids is significant and linked with the stages of development of the plants, the dates of which vary each year slightly due to naturally occurring changes in climate. The conducted research proved that the weather conditions primarily determine the yield and quality of hop cones. The area of the Małopolski Poland Vistula Gorge, where the research was conducted, is a region where hops not only achieve high, but also very good quality crops [12,44]. From the analysis of the percentage share of individual sources of variation and their interaction in the total variability of the studied characteristics, it was determined that the variety significantly determines the size and quality of hop cones, on average in $13.3 \%$, with fluctuations from $3.5 \%$ for the share of beta-acids to $29,5 \%$ for the number of nodes per cone spindle of hop. Two-fold interactions: variation $x$ years; years $x$ location, or the triple interaction of years' $x$ locations $x$ varieties are also important for the phenotypic variability. However, the smallest share of variance in the phenotypic variance was found for the localization of the experiment, with a share of 0.1 to $15.2 \%$ in the overall variance. Czech [16] and Slovenian [2] studies show similar relationships.

Particularly important for the quality of cones was the cone length of the spindle and the number of nodes per cone spindle of hop. Fewer nodes per cone spindle indicate that the leaves and lupulin and the specific substances of hops present in it are greater. The cone length of spindle turned out to be a varietal feature. According to the European detailed rules for the certification of hops and hop products [30], in the case of high-quality hops, share of spindle was $8-10 \%$, in medium-quality cones-10-12\%. In the "common" cones $12-14 \%$ while in wild hop cones-up to $17 \%$.

The index of cone density and the index of specific weight of hop cones indicated their good quality. Usually, it ranges from 0.8 to 1.2. On its basis, "specifically light" hops with large, but light cones and "specifically heavy" hops are calculated, which usually have more lupulin, so they are more appreciated by brewers [12,14].

The bitterness and aroma content of the hops in this region is high. This is due to the specificity of the climate in which this region is located. Due to the proximity of the Vistula River, the weather conditions, sufficiently humid air, and air temperatures in this area provide the hop plants with suitable conditions for vegetation. Apart from the climate, soil conditions are another important factor for the development of hops. The soil conditions of the Małopolski Poland Vistula Gorge had a positive effect on the content of hop resins and oils in hop cones.

The quality of the hop cones depended not only on the variety, but also on the growing conditions and climatic and soil factors affecting the plants during the growing season. The studies of other authors $[11,12,14,45]$ show that the chemical components of hops are subject to further changes during harvesting, drying and storage, therefore the processing of the raw material must be carried out with particular care to not to lose valuable ingredients and thus reduce its brewing value [4]. The term "quality" in connection with hop products can be defined as the degree of loss of hop constituents from harvesting to dosing at the brewhouse. The road is long and includes: the already mentioned hop harvesting and its storage, the processing of hop cones into hop products and their storage, transport to the brewery, storage before use, and finally the dosing method. During all these stages, mainly as a result of oxidation, valuable components of hops are lost: alpha-acids, sesquiterpenes, or low-molecular polyphenols; on the other hand, however, the content of unfavorable hard resins is increased. This process is known as "aging" of the hops. The key factors here are: temperature, time, and environment in which the hop products are kept. The sensory features of beer, including its aroma, taste, and bitterness, largely depend on the quality of hops and their products $[2,12,15]$. Aging hops causes not only a reduction in the amount of its desired ingredients, but also changes in its antioxidant activity and the profile of hop oils, therefore, the collection of cones should be carried out on time, in accordance with the $\mathrm{BBCH}$ scale [46]. 
The influence of geographic location and weather conditions during the growing season are as important as genetic factors [2,16]. According to Szewczuk [14], during the hop growing season, it is desirable to gradually increase air temperatures and rainfall, from the beginning of April to the end of July. In June (the main period of intensive growth and formation of side shoots), in July (the period of flowering and cone formation) and in August (period of cones formation and maturation) the average air temperature should oscillate around $18{ }^{\circ} \mathrm{C}$. It is assumed that the annual rainfall in the amount of $600 \mathrm{~mm}$, respectively, distributed during the growing season, satisfies the water needs of hops in Polish climatic conditions $[1,14,47]$. Srečec et al. [48] proved that weather conditions during the vegetation of hop plants have a stronger influence on the accumulation of alpha-acids and the maturity of cones than soil conditions. Hops tolerate annual temperatures from 5.6 to $21.3^{\circ} \mathrm{C}$ [49]. The average annual temperature in the area of the Małopolska Poland Vistula Gorge in 2015,2016 and 2017 , was, respectively, $12.9^{\circ} \mathrm{C} ; 13.4^{\circ} \mathrm{C} ; 13.1^{\circ} \mathrm{C}$, in line with the needs of hops. The photosynthetic activity of hops is mainly determined by temperature. Kondić et al. [2] proved that hop plants obtain maximum carbon assimilation at air temperatures from $21^{\circ}$ to $39^{\circ} \mathrm{C}$, of course with sufficient water supply $[14,50]$. These temperatures in the study area are typical only for July and August. In the northern hemisphere, rainfall sufficient for hops is almost $100 \mathrm{~mm}$ per month [51]. The total annual precipitation in the region of the Małopolska Poland Vistula Gorge in 2015 was $328 \mathrm{~mm}$, while in 2016 it was $337.5 \mathrm{~mm}$ and 467 in 2017, so they were lower than in the studies of Eriksen et al. [51]. The total amount of precipitation in the study area is, however, relatively consistent with the hop demand, the temperatures in the summer months are, however, relatively high, and drought is also possible. Hops prefer soils with a p ranging from 6.0 to 6.5 , but they also grow on soils with a $\mathrm{pH}$ of 4.8 to $8.0[1,10,14]$. Soil samples in our research obtained $\mathrm{pH}$ values from 5.9 to 7.3 , therefore it is presumed that the $\mathrm{pH}$ value was not a limiting factor. Across Europe, only a small percentage of hop plantations are irrigated. Periods of drought and irregular rainfall reduce the biosynthesis of secondary metabolites and the vigor of hops, resulting in a reduction in the production of alpha acids and essential oils [52]. Srečec et al. [47] assessed the influence of weather conditions on the level of alpha acids during the growing season of cv. Aurora in Slovenia. They found that there is an inverse correlation between mean daily air temperatures and alpha acid productions $(r=-0.39)$ and a strong positive correlation between rainfall sum and alpha acid production $(\mathrm{r}=0.46)$. In opinion Lewandowski [12], Szewczuk [14] and Eriksen et al. [51], the air temperatures in July and August exert a significant influence on the development of alpha-acids. The influence of weather conditions on the content of alpha-acids in hop cones was confirmed in the conducted research.

Donner et al. [16] proved that in the Czech Republic, rainfall was the most important factor that had a positive impact on the hop yield with correlations $r=0.59$ and 0.61 for the sum of seasonal rainfall (April-August), $\mathrm{r}=0.65$ and 0.60 for daily precipitation $>3 \mathrm{~mm}$, $r=0.37$ and 0.58 for precipitation in May and $r=0.50$ and $r=0.32$ in July. The amount of rainfall did not statistically affect the yield of all hop varieties, such as 'Sládek', 'Premiant' and 'Agnus', while the positive influence of the level of irrigation on the yield increase was shown by the correlation $r=0.58,0.55$ and 0.49 . The most important factor negatively affecting the alpha-acid content was high air temperatures in summer, the correlations of which ranged from $r=-0.56$ to -0.83 .

The morphological characterization of agricultural plants usually precedes the chemical one as well as the molecular one. The economic quality of hops turned out to be more related to the morphological features of the plants, while the chemical properties of the cones are more important for the brewing of beer. The average length of the cones of the researched hop varieties ranged from 29.5 to $41.0 \mathrm{~mm}$, but the 'Lubelski' variety $(41 \mathrm{~mm})$ had the longest cones. Cones turned out to be longer than those obtained from Czech hop varieties, which were only $37.0 \mathrm{~mm}$ long [24]. Cone length of the spindle in the examined varieties ranged from 17.1 to $28.6 \mathrm{~mm}$, and the highest value of this feature was characterized by the variety 'Magnum'. However, the 'Sybilla' variety was characterized 
by a higher the number of nodes per cone spindle of hop. The cone length of spindles of the Norwegian and Danish hop genotypes reached $43.0 \mathrm{~mm}$, which was related to the geographical location (latitude and longitude) [26]. The plants of the researched hop varieties differed significantly in cone length of spindle. Variety 'Magnum' stood out with the longest spindles of cones, while the 'Marynka' variety represented the shortest spindles of the cones.

The central axis or hop spindle has a zigzag shape. The morphological characteristics of the spindle (cone spindle) is an important aspect, not only from the breeding point of view, but it should also have a relatively larger number of knots and shorter internodes, which ensures the compactness of the cones, and thus prevents of the loss of the lupulin glands [12]. The two varieties: 'Magnum' and 'Sybilla' had the highest number of nodes per cone spindle of hop, and these varieties should be characterized by the highest content of lupulin.

Chemical analysis is the most objective evaluation of hops from a technological point of view. There are three groups of compounds that go into solution during the boiling of the wort. These are: bitter substances (nourishing substances), which, depending on the variety, accounted for $15-25 \%$ of the DM of cones, tannins (2-65) and essential oils $(0.5-2.5 \%)$. Hops essential oils are most commonly used in the brewing of beer, but can also be found in pharmacological products. Volatile aroma compounds of hops are of key importance for brewers, as they give the beer a unique hop aroma [53]. Hops oils are one of the most complex essential oils among the known and cultivated plants $[49,54]$. About 200 studies on the composition of hop oil have been published so far. The number of identified volatile compounds in hop oils continues to grow. Holt et al. [54] and Dietz et al. [55] believe that over 1000 volatile compounds are present in hops oil. However, it is still unclear which of the volatile components in the hops are directly transferred to the beer without undergoing biochemical changes such as esterification or enzymatic cleavage. Volatile components of hops are a very heterogeneous and complex mixture of hundreds of compounds in a certain concentration range, but their influence on the beer aroma is not directly proportional to their concentrations [49]. The presence and concentration of hop compounds is influenced by many factors, such as variety, location, geographic location, and conditions of plant growth and development $[43,49,53,55]$. In the conducted research, the chemical composition was analyzed, and the composition of essential oils and the alpha-acid content of 6 varieties of hops grown in 4 different locations were verified. The dried hop cones contained 0.7 to $2.6 \%$ of hop oil containing aromas and flavors belonging to several chemical classes, such as terpenes, alcohols, esters, aldehydes, and ketones. Both the amount and composition of hops oil are largely dependent on genetic factors, age of the hops or rootstock, growth conditions including soil, $\mathrm{pH}$, carbon, nitrogen and moisture content, microbial weight, etc., but also on climatic conditions (temperature, humidity, sunshine, wind speed and direction) and from time from harvest [56,57].

According to Eyres and Dufour [53] the amount of essential oil and the proportions of individual fractions differ in different hop varieties. For example, the amount and composition of oxides, epoxides, and alcohols in the sesquiterpenes fraction varies widely between hop varieties. Resins and essential oils, as secondary metabolites, are the main ingredients in hop brewing. They are synthesized and accumulate in the lupulin glands found in the cones produced by female plants (H. lupulus L.). Some of the soft resins are hop acids. Composed of two chemically similar groups of compounds, such as alpha acids or humulones and beta acids or lupulones, they are mainly used in the beer brewing process and have both preservative and bitter properties. Alpha acids also contribute to microbial stability and enhance foam stability [57,58]. MacKinnon et al. [43] proved that the development of alpha-acids in hop cones takes place from the beginning of cone formation. The development of two weeks earlier, however, is of key importance for the harvest of hop cones, because $90 \%$ of alpha acids are formed during this time [2,4,59]. Compounds from the group of resins, especially alpha, are of the greatest importance in beer production. Alpha-acids give the beer a characteristic, bitter taste [11,60]. The chemical composition of 
hop cones was varied. The content of alpha acids was depending on the genotype. The varieties 'Magnus' and 'Iunga' stood out with the highest proportion of alpha acids.

Among the tested compounds from the group of hydrocarbons significantly affecting the aroma of hop cones, myrcene was characterized by an unpleasant, pungent odor, so it is a compound unfavorable in the bouquet of hop aroma. The 'Magnum' variety had the most favorable ratio of the myrcene to the humulene for the brewing industry.

\section{Future}

The conducted research shows that genetic features significantly determine the quality of hop cones. The natural conditions and geographical location are also important. The area of the Małopolski Poland Vistula Gorge is a region where hops not only achieve high, but also good-quality crops. The bitterness and aroma of hop cones in this region are high. This is due to the specificity of the climate in which this region is located. Sufficient humidity and air temperature in this area provide the hop plants with suitable conditions for vegetation.

In the region of the Małopolski Poland Gorge of the Vistula, where there is a high concentration of hop cultivation, effective instruments should be developed to manage the cultivation and breeding of this species, such as:

Promotion of the raw material, which will positively affect the acquisition of new recipients, which may increase the demand and encourage farmers to cultivate this species;

Trainings on the protection and fertilization of plants, which will enable obtaining a better raw material for beer production;

Breeding of more efficient and disease-resistant and pest-resistant varieties of hops, which will reduce yield losses and improve its quality;

Construction of a dried hop processing plant;

Development and support for farms, which will enable their competitiveness in relation to the countries of Western Europe;

Introducing new, innovative technologies in the cultivation of hops, which will facilitate the work of farmers.

The preparation and knowledge of farmers from the Małopolska Gorge of the Vistula region is a key factor in the cultivation of hops. In addition to theoretical knowledge acquired during courses and training, they also have experience passed down from generation to generation. Therefore, it is important to support and promote this niche branch of agriculture that supplies both breweries and pharmaceutical companies with raw material.

\section{Conclusions}

Favorable weather conditions meant that the hop plants in 2015-2017 had good conditions for development. The highest weight of both fresh and dry mass of cones was obtained by the 'Magnum' variety, and the 'Sybilla' variety was homologous in this trait.

The highest index of specific weight of cones was obtained by the 'Marynka' variety, the 'Sybilla' variety had the highest cone compactness index.

In the tested cultivars, the content of alpha acids ranged from 6 to $11.8 \%$. Hop aromatic oils were important from the point of view of the beer production process. Several of these compounds have been identified (myrcene, humulene, farnesene and caryophyllene). The most important for the production of beer the humulene constituted from 18 to $32 \%$, depending on the variety and location of plantation. By selecting the raw material from these varieties, it is possible to properly shape the flavor characteristics of the beer. Breeders should try to ensure that new varieties meet the high quality requirements and, at the same time, high yield of cones.

In the essential oils of the studied hop varieties, compounds with myrcene and $\alpha-$ humulene dominating the profiles were identified. The varieties 'Iunga', 'Sybilla' and 'Lubelski' were rich in monoterpene hydrocarbons, mainly myrcene, while sesquiterpenes hydrocarbons, mainly $\alpha$-humulene, were more abundant in the 'Marynka' variety. The 
'Magnum' variety was characterized by an even distribution of monoterpenes and sesquiterpenes. The 'Lomik' variety obtained the result at the level of the average for the varieties.

Variety 'Magnum' can be recommended for beer production, not only in this region, but also throughout Poland, as an important area of hop production in Europe. This variety are characterized by important advantages (high alpha-acid content, quite high Myrcene to humulene ratio), which predisposes it to beer fermentation.

The greatest stability of alpha-acids was observed for the 'Sybilla' variety, and the lowest for the 'Magnum' variety, which is very important when the raw material is stored for a longer time and used in the production of beer.

The stability of bitter hop acids, depending on the type of hops, provides valuable information on the possibility of long-term storage without significant losses of valuable secondary metabolites used by the brewing industry.

The bitterness and aroma content of the hops in this region is high. This is due to the specificity of the climate in which this region is located.

Author Contributions: Conceptualization: B.S., M.Ś., P.P., B.K.-M. and A.K.-D.; methodology. B.S., A.K.-D., B.B.; software. D.S., P.P.; validation. D.S., B.B.; formal analysis. B.S., M.Ś.; investigation. B.S.; P.P., resources. D.S., B.B.; data curation B.B.; A.K.-D., writing—original draft preparation. B.S., A.K.-D.; writing—review and editing. B.S., B.K.-M.; visualization. D.S.; P.P. supervision. B.S., B.K.-M.; project administration. B.S., A.K.-D.; funding acquisition B.S. All authors have read and agreed to the published version of the manuscript.

Funding: This research received no external funding.

Institutional Review Board Statement: Not applicable.

Informed Consent Statement: Not applicable.

Data Availability Statement: Not applicable.

Conflicts of Interest: The authors declare no conflict of interest.

\section{References}

1. Skomra, U.; Kawka-Lipińska, M. Guide to the Hop Protection Signaler; IUNG-PIB: Puławy, Poland, 2018; p. 72. ISBN 978-83-7562-281-2.

2. Kondić, D.; Cerenak, A.; Košir, I.J.; Ocvirk, M.; Krmpot, T.; Đurić, G. Morphological and Biochemical Characterization of Wild Hop (Humulus lupulus L.) Populations from Banja Luka Area (Bosnia and Herzegovina). Agronomy 2021, 11, 239. [CrossRef]

3. Skomra, U. The Role of Scientific Research in Shaping Progress in the Production of Hops and Tobacco; Institute of Soil Science and Plant Cultivation-National Research Institute: Puławy, Poland, 2012; pp. 10-30. (In Polish)

4. Skomra, U. Factors influencing the quality of hops and their products during processing and storage. Ferment. Fruit Veg. Ind. 2015, 4, 37-38. (In Polish)

5. Solarska, E. Good Agricultural Practices in Integrated Production with the Use of Beneficial Microorganisms in Hop Cultivation; EM Ecosystem Association-Nature's Heritage: Warsaw, Poland, 2012; pp. 19-60. (In Polish)

6. Dwornikiewicz, J.; Migdal, J.; Solarska, E.; Stasiak, M.; Zaorski, T. Hops Grower's Guide; Institute of Soil Science and Plant Cultivation: Puławy, Poland, 1996; p. 54. (In Polish)

7. Dwornikiewicz, J. Phytosanitary and Agrotechnical Principles of Hop Planting; Institute of Soil Science and Plant Cultivation-National Research Institute: Puławy, Poland, 2006; pp. 5-17.

8. Astray, G.; Gullón, P.; Gullón, B.; Munekata, P.E.S.; Lorenzo, J.M. Humulus lupulus L. as a Natural Source of Functional Biomolecules. Appl. Sci. 2020, 10, 5074. [CrossRef]

9. FAOSTAT. Crops. 2019. Available online: http://www.fao.org/faostat/en/\#data/QC (accessed on 29 May 2021).

10. Dwornikiewicz, J. Regionalization of hop production in Poland. Pamiętnik Puławski 2002, 130, 125-134. (In Polish)

11. Dwornikiewicz, J. Regional differentiation of hop production in Poland. Wieś Jutra 2006, 12, 37-38.

12. Lewandowski, A. Comprehensive Research on the Economic Value of Hop Varieties in 1988-1995; Variety Studies, Issue 77; COBORU: Słupia Wielka, Poland, 2003; p. 85. ISSN 1231-823X. (In Polish)

13. Skomra, U. Polish Varieties of Hops; Institute of Soil Science and Plant Cultivation-National Research Institute: Puławy, Poland, 2010; p. 60.

14. Szewczuk, C. Hop. In Growing Plants; Kotecki, A., Ed.; University of Life Science in Wroclaw: Wroclaw, Poland, 2020; Volume 3, pp. 537-558. ISBN 978-83-7717-342-8.

15. Dwornikiewicz, J. Current State and Prospects of Hop Cultivation in Poland until 2020; Studia i Raporty IUNG-PIB: Puławy, Poland, 2009; Volume 133, pp. 133-145, (In Polish). [CrossRef] 
16. Donner, P.; Pokorný, J.; Ježek, J.; Krofta, K.; Patzak, J.; Pulkrábek, J. Influence of weather conditions, irrigation and plant age on yield and alpha-acids content of Czech hop (Humulus lupulus L.) cultivars. Plant Soil Environ. 2020, 66, 41-46. [CrossRef]

17. PN-R-04031: 1997. Chemical and Agricultural Analysis of Soil-Sampling. Food, Agriculture and Forestry Sector; Technical Committee 90, Soil Cultivation and Horticulture: Warsaw, Poland, 1997; p. 5.

18. Bartmiński, P.; Krusińska, A.; Bieganowski, A.; Ryżak, M. Preparation of soil samples for grain size distribution analysis using the laser diffraction method. Roczniki Gleboznawcze Soil Sci. Annu. 2011, 62, 9-15. (In Polish)

19. KQ/PB-75 Revision 04 of March 26, 2018 Particle Size Distribution in the Particle Range (0.02-2000) $\mu \mathrm{m}$ Range (0.01-99.99), Laser Diffraction Method. Scope of Accreditation No. AB 1186. Available online: https://www.pca.gov.pl/en/accreditedorganizations/accredited-organizations/testing-laboratories/ (accessed on 31 May 2021). (In Polish)

20. ISO 10390: 2005. Soil Quality-Determination of $\mathrm{pH}$. Available online: https:/ / www.iso.org/standard/40879.html (accessed on 31 January 2021).

21. KQ/PB-34. Version 05 from 01/07/2014. Organic Carbon Content. Scope of Accreditation No. AB 1186. Available online: file: / / C: /Users / Barbara/Downloads / AB\%201186\%20(2).pdf (accessed on 31 May 2021).

22. Mocek, A. Soil Science; State Scientific Publisher: Warszawa, Poland, 2015; p. 571.

23. PN-R-04020: 1994 + AZ1: 2004. Chemical and Agricultural Analysis of Soil; Polish Committee for Standardization: Warsaw, Poland, 2004. (In Polish)

24. PN-R-04023: 1996. Chemical and Agricultural Analysis of Soil. In Determination of the Available Phosphorus Content in Mineral Soils; Polish Committee for Standardization: Warsaw, Poland, 1996. (In Polish)

25. PN-R-04022: 1996 + AZ1: 2002. Chemical and agricultural analysis of soil. In Determination of Available Potassium in Mineral Soils; Polish Committee for Standardization: Warsaw, Poland, 2002. (In Polish)

26. PN-R-04017: 1992. Content of Copper Soluble in HCl. In Mineral Soil; Polish Committee for Standardization: Warsaw, Poland, 1992. (In Polish)

27. PN-R-04019: 1993. Content of Manganese Soluble in HCl in Mineral Soil; Polish Committee for Standardization: Warsaw, Poland, 1993. (In Polish)

28. PN-R-04021: 1994. Content of Iron Soluble in HCl in Mineral Soil; Polish Committee for Standardization: Warsaw, Poland, 1994. (In Polish)

29. PN-R-04018: 1993. Content of Boron Soluble in HCl in Mineral Soil; Polish Committee for Standardization: Warsaw, Poland, 1993. (In Polish)

30. Commission regulation (EC) No 1850/2006 of 14 December 2006 laying down detailed rules for the certification of hops and hop products. Off. J. Eur. Union 2006, 355, 72-87.

31. PN-A-79097: 2001. Hop Granules and Extracts; PKN: Warsaw, Poland, 2001.

32. European Brewery Convention. Analytica-EBC, Section 7. Hops, Method 7.10. Hop Oil Content in Hops and Hop Products; Fachverlag Hans Carl: Nürnberg, Germany, 2002.

33. European Brewery Convention. Analytica-EBC, Section 7. Hops, Method 7.12. Hops Essential Oils by Capillary Gas Chromatography, Flame Ionization Detection; Fachverlag Hans Carl: Nürnberg, Germany, 2006.

34. McAdam, E.L.; Vaillancourt, R.E.; Koutoulis, A.; Whittock, S.P. Quantitative genetic parameters for yield, plant growth and cone chemical traits in hop (Humulus lupulus L.). BMC Genet. 2014, 15, 22. [CrossRef] [PubMed]

35. Kondracki, J. Regional Geography of Poland; Scientific Publishers PWN SA: Warsaw, Poland, 2013.

36. Woś, A. Polish Climate; Polish Scientific Publishers PWN: Warsaw, Poland, 1999; EAN: 8301127805.

37. PTG 2008. Particle Size Distribution and Textural Classes of Soils and Mineral Materials-Classification of Polish Society of Soil Science 2008. Rocz. Glebozn. 2009, 60, 5-16.

38. Nawrocki, S. Fertilizer Recommendations. Part. I. Limit Numbers for Valuation of Soils in Macro and Microelements; IUNG: Puławy, Poland, 1985; p. 38.

39. Skowera, B.; Kopcińska, J.; Kopeć, B. Changes in thermal and precipitation conditions in Poland in 1971-2010. Ann. Warsaw Univ. Life Sci. SGGW. Land Reclam. 2014, 46, 153-162. [CrossRef]

40. SAS Institute Inc. SAS/STAT®9.2 User's Guide; SAS Institute Inc.: Cary, NC, USA, 2008.

41. Trętowski, J.; Wójcik, R. Methodology of Agricultural Experiments; University of Agriculture and Education: Siedlce, Poland, 1991; p. 500. (In Polish)

42. Crossa, J.; Franco, J. Statistical methods for classifying genotypes. Euphytica 2004, 153, 19-37. [CrossRef]

43. MacKinnon, D.; Pavlovič, V.; Čeh, B.; Naglič, B.; Pavlovič, B. The impact of weather conditions on alpha-acid content in hop (Humulus lupulus L.) cv. Aurora. Plant Soil Environ. 2020, 66, 519-525. [CrossRef]

44. Lewandowski, A. Syntheses of the Results of Varietal Experiments. Hop. 1991-1995; No 1082; COBORU: Słupia Wielka, Poland, 1996; p. 18. ISSN 1232-0927.

45. Salantă, L.C.; Coldea, T.R.; Ignat, M.V.; Pop, C.R.; Tofană, M.; Mudura, E.; Bors, A.; Pasqualone, A.; Zhao, H. Non-Alcoholic and Craft Beer Production and Challenges. Processes 2020, 8, 1382. [CrossRef]

46. Feller, C.; Bleiholder, H.; Buhr, L.; Hack, H.; Hess, M.; Klose, R.; Meier, U.; Stauss, R.; Boom, T.; Weber, E. Phenological growth stages of vegetable crops. II. Fruit vegetables and pulses. Co-ding and description according to the extended BBCH scale with illustrations. Nachr. des Dtsch. Pflanzenschutzd. 1995, 47, 217-232. 
47. Srečec, S.; Kvaternjak, I.; Kaučić, D.; Špoljar, A.; Erhatič, R. Influence of climatic conditions on accumulation of $\alpha$-acids in hop clones. Agric. Conspec. Sci. 2008, 73, 161-166.

48. Srečec, S.; Čeh, B.; Ciler, T.S.; Rus, A.F. Empiric mathematical model for predicting the content of alpha-acids in hop (Humulus lupulus L.) cv. Aurora. Springer Plus 2013, 2, 59. [CrossRef] [PubMed]

49. Arruda, T.R.; Pinheiro, P.F.; Silva, P.I.; Bernardes, P.C. A new perspective for a well-recognized raw material: Phenol content, antioxidant and antimicrobial activity, and the $\alpha$ - and $\beta$-acid profile of Brazilian hop extracts (Humulus lupulus L.). LWT 2021, 141, 110905. [CrossRef]

50. Biendl, M.; Engelhard, B.; Forster, A.; Gahr, A.; Lutz, A.; Mitter, W.; Schmidt, R.; Schonberger, C. Hops. Their Cultivation, Composition and Usage; Fachverlag Hans Carl GmbH: Nuremberg, Germany, 2014; ISBN 9783418008233.

51. Eriksen, R.L.; Rutto, L.K.; Dombrowski, J.E.; Henning, J.A. Photosynthetic Activity of Six Hop (Humulus lupulus L.) Cultivars under Different Temperature Treatments. Hort Sci. 2020, 55, 403-409. [CrossRef]

52. De Keukeleire, J.; Janssens, I.; Heyerick, A.; Ghekiere, G.; Cambie, J.; Roldán-Ruiz, I.; Van Bockstaele, E.; De Keukeleire, D. Relevance of organic farming and effect of climatological conditions on the formation of $\alpha$-acids, $\beta$-acids, desmethylxanthohumol and xanthohumol in hop (Humulus lupulus L.). J. Agric. Food Chem. 2007, 55, 61-66. [CrossRef]

53. Eyres, G.; Dufour, J.-P. Hops Essential Oil: Analysis, Chemical Composition, and Odor Properties. In Beer in Health and Disease Prevention; Preedy, V.R., Ed.; Academic Press: London, UK, 2009; pp. 239-254. [CrossRef]

54. Holt, S.; Miks, M.H.; de Carvalho, B.T.; Foulquié-Moreno, M.R.; Thevelein, J.M. Molecular biology of fruit and flower aromas in beer and other alcoholic beverages. FEMS Microbiol. Rev. 2018, 43, 193-222. [CrossRef] [PubMed]

55. Dietz, C.; Cook, D.; Huismann, M.; Wilson, C.; Ford, R. The multisensory perception of hop essential oil: A review. J. Inst. Brew. 2020, 126, 320-342. [CrossRef]

56. Van Holle, A.; Van Landschoot, A.; Roldán-Ruiz, I.; Naudts, D.; De Keukeleire, D. The brewing value of Amarillo hops (Humulus lupulus L.) grown in the northwest United States: A preliminary study of the importance of terroir. J. Inst. Brew. 2017, 123, 312-319. [CrossRef]

57. Moir, M. Hops-A millennium review. J. Am. Soc. Brew. Chem. 2000, 58, 131-146. [CrossRef]

58. Steenackers, B.; De Cooman, L.; De Vos, D. Chemical transformations of characteristic hop secondary metabolites in relation to beer properties and the brewing process: A review. Food Chem. 2015, 172, 742-756. [CrossRef]

59. Hecht, S.; Kammhuber, K.; Reiner, J.; Bacher, A.; Eisenreich, W. Biosynthetic experiments with tall plants under field conditions. $18 \mathrm{O} 2$ incorporation into humulone from Humulus lupulus. Phytochemistry 2004, 65, 1057-1060. [CrossRef]

60. Pavlovič, V.; Pavlovič, M.; Čerenak, A.; Košir, I.J.; Čeh, B.; Rozman, Č.; Turk, J.; Pažek, K.; Krofta, K.; Gregoric, G. Environment and weather influence on quality and market value of hops. Plant Soil Environ. 2012, 58, 155-160. [CrossRef] 